\title{
Nickel Boride Catalyzed Reductions of Nitro Compounds and Azides: Nanocellulose-Supported Catalysts in Tandem Reactions
}

\author{
Giampiero Proiettia \\ Kaniraj Jeya Prathapa \\ Xinchen $\mathrm{Ye}^{\mathrm{b}}$ \\ Richard T. Olsson ${ }^{b}$ \\ Peter Dinér*a \\ a Division of Organic Chemistry, Department of Chemistry, \\ School of Engineering Sciences in Chemistry, Biology and \\ Health, KTH - Royal Institute of Technology, Teknikringen 30 , \\ 10044 Stockholm, Sweden \\ diner@kth.se \\ b Department Fiber and Polymer Technology, School of \\ Engineering Sciences in Chemistry, Biotechnology and Health, \\ KTH - Royal Institute of Technology, 10044 Stockholm, \\ Sweden
}
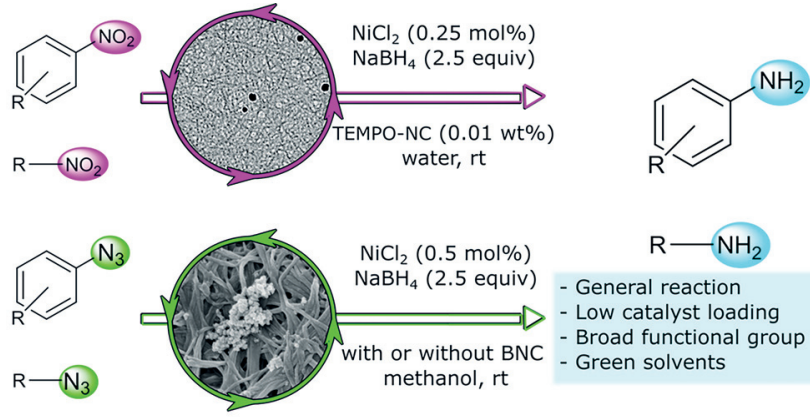

$\mathrm{NiCl}_{2}(0.5 \mathrm{~mol} \%)$ $\mathrm{NaBH}_{4}$ (2.5 equiv) $\mathrm{R}-\mathrm{N}_{3}$

with or without BNC methanol, $\mathrm{rt}$
Received: 08.06.2021

Accepted after revision: 05.08.2021

Published online: 05.08 .2021

DOI: 10.1055/a-1579-2190; Art ID: ss-2021-t0339-fa

License terms: (CC)

(c) 2021. The Author(s). This is an open access article published by Thieme under the terms of the Creative Commons Attribution License, permitting unrestricted use, distribution and reproduction, so long as the original work is properly cited. (https://creativecommons.org/licenses/by/4.0/)

Abstract Nickel boride catalyst prepared in situ from $\mathrm{NiCl}_{2}$ and sodium borohydride allowed, in the presence of an aqueous solution of TEMPO-oxidized nanocellulose $(0.01 \mathrm{wt} \%)$, the reduction of a wide range of nitroarenes and aliphatic nitro compounds. Here we describe how the modified nanocellulose has a stabilizing effect on the catalyst that enables low loading of the nickel salt pre-catalyst. Ni-B prepared in situ from a methanolic solution was also used to develop a greener and facile reduction of organic azides, offering a substantially lowered catalyst loading with respect to reported methods in the literature. Both aromatic and aliphatic azides were reduced, and the protocol is compatible with a one-pot Boc-protection of the obtained amine yielding the corresponding carbamates. Finally, bacterial crystalline nanocellulose was chosen as a support for the Ni-B catalyst to allow an easy recovery step of the catalyst and its recyclability for new reduction cycles.

Key words $\mathrm{Ni}-\mathrm{B}$, nickel boride, nitro reduction, azide reduction, nickel boride catalyzed hydrogenation, TEMPO nanocellulose, crystalline nanocellulose

\section{Introduction}

Aromatic and heteroaromatic amines are important intermediates in the chemical and pharmaceutical industry. ${ }^{1}$ There are several different ways to produce these compounds and the most used synthetic routes are the hydrogenation $^{2}$ of nitroarenes (Scheme 1) and metal-catalyzed $\mathrm{C}-\mathrm{N}$ coupling chemistry. During recent years, nanostructured particles (NPs) have emerged as important in catalysis due to their high catalytic activity and high surface areas. Several NPs have been utilized for nitroarene reduc- tions $^{3}$ using both precious metals (gold, ${ }^{4}$ platinum, ${ }^{5,6}$ palladium ${ }^{5,7}$ ) and cheaper, more abundant metals (e.g., cobalt, ${ }^{8}$ nickel, ${ }^{9}$ iron $\left.{ }^{10}\right)($ Scheme 1$)$. There is a drive to develop routes for organic reactions in 'green' solvents, e.g., water. Recently, Lipshutz and co-workers developed a mild and ligand-free procedure with $\mathrm{Fe} / \mathrm{Pd}$ nanoparticles that catalyzed the reduction of nitroarenes at room temperature in water using sodium borohydride in the presence of a designed PEG surfactant (Scheme 1). ${ }^{11}$ However, the green methodologies based on more abundant and cheaper transition metals, such as nickel, are challenging. In the early 1950s, Schlesinger et al. and Paul et al. reported that the reduction of nickel salts with sodium borohydride in aqueous or alcoholic solvents gave a finely divided black precipitate that contained both nickel and boron, i.e., nickel boride. $^{12,13 a, b}$
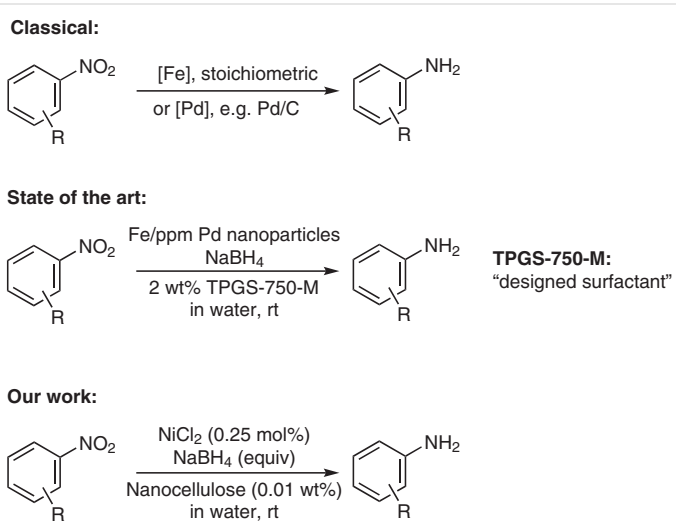

Scheme 1 Methods for the synthesis of anilines from nitroarenes

The Ni-B catalyzes the decomposition of sodium borohydride into hydrogen, but it also promotes different hydrogenation reactions with similar activity as Raney 


\section{Biographical Sketches}
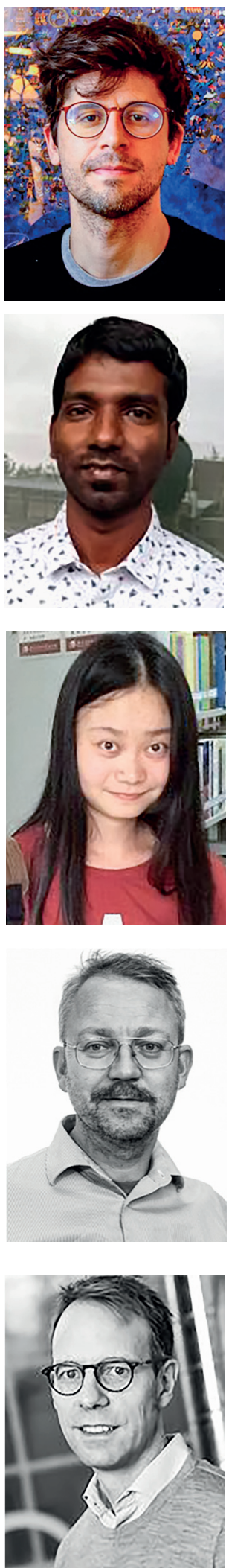

Giampiero Proietti obtained his M.Sc. from 'La Sapienza University of Rome' in 2015 with a thesis work on the synthesis of a photo- and thermo-responsive polymer. He joined Peter Diner's

Kaniraj Jeya Prathap obtained his Ph.D. in 2012 at the Central Salt and Marine Chemicals Research Institute (Bhavnagar, Gujarat, India) working mainly with asymmetric catalysis. After a short stay at the Institute of Organic Chemistry and Biochemistry of the Czech Academy of Sciences (IOCB Prague, Czech Republic),

Xinchen Ye MSc Xinchen Ye is a Ph.D. student at KTH Royal Institute of Technology (Sweden). She received a master's degree

Richard T. Olsson is an Assoc. Prof. at KTH Royal Institute of Technology, Stockholm, Sweden, in the Department of Fibre and Polymer Technology. He received his Ph.D. from $\mathrm{KTH}$ in

Peter Dinér obtained his Ph.D. in 2005 at University of Gothenburg. In 2006, he joined Prof. K. A. Jørgensen at Center for Catalysis at Aarhus University working on enantioselective organocatalysis. He moved back group at the Royal Institute of Technology in 2017 as Ph.D. student and his research revolves around organic azides, developing methodologies for their reduction or exploiting the

unique reactivity of perfluorinated aromatic azides in a photo-promoted synthesis of optical active sulfonimidamides and their applications in materials.

he was awarded a post-doctora grant (PBC \& Lady Davis Postdoctoral Fellow) to join Prof. Maayan at Technion - Israel Institute of Technology to work with novel peptidomimetics In 2016, he was awarded the Wenner-Gren postdoctoral fellowship to join Prof. Dinér's group at KTH - Royal institute of Technology (Stockholm, Sweden) to

in chemical engineer degree from KTH in 2017. Her current Ph.D. project focuses on the synthesis and characterization work on nickel boride catalyzed reduction using nanocellulose. In 2019, Dr. Prathap joined Wageningen University \& Research (Netherlands) as a senior postdoctoral fellow working on synthesis of therapeutic peptides. Currently, he works as a researcher at the University of Groningen.

of protein nanofibrils from whey and composites made thereof.
2007 on processing of microwave absorbing nanocomposite materials. His postdoctora studies were at the CSIC, Spain, with a focus on sustainable nanomaterials. $\mathrm{He}$ is editor of
Scientific Reports, and his research focuses on nanocomposite materials and inorganic/polymeric interfaces for sustainable material engineering in novel applications. to University of Gothenburg under the guidance of Prof. M. Grøtli working on medicinal chemistry. In 2010 he started his independent research group at Uppsala as an Assist. Prof. In 2013, he was granted a position as an Assoc. Prof. at the Royal Institute of Technology, Department of Chemistry, where his research centers around metaland organocatalysis and since 2015 he acts as the Head of Division of Organic Chemistry. 
nickel. ${ }^{13 c}$ The nickel boride material has mainly been used in organic synthesis as a stoichiometric reagent, particularly in the hydrogenation of alkenes and alkynes, ${ }^{14}$ reduction of $\mathrm{N}$-heterocycles, ${ }^{15}$ reduction of nitroarenes, ${ }^{16}$ deoxygenation reactions, desulfurization reactions, dehalogenation reactions, etc. ${ }^{17}$ However, only a few catalytic applications have been reported. ${ }^{18}$

The main reasons for the use of stoichiometric amounts of nickel boride are related to the inherent instability of the material in aqueous media under oxygen-containing atmosphere in which the nickel boride converts into nickel oxide and nickel metal. ${ }^{19}$ A potential solution to the instability of nickel nanoparticles is to use a support for the nickel boride nanoparticles. A support can stabilize the nanoparticles and enables easier recyclability of the nanoparticles, which is important due to the possible toxicity and sensitizing effects of nickel. ${ }^{20}$ In recent years, nanocellulose (NC) derivatives have been studied as potentially efficient, cheap, and renewable supports for catalysis. ${ }^{21}$ The use of nanocelluloses as supports for NP catalysts is appealing due to their high surface area (300-450 $\mathrm{m}^{2} /$ gram) ${ }^{21,22}$ The natural functionality of the celluloses depends on the reactive hydroxyl groups present in the glucose repetitive units in the cellulose crystals. ${ }^{23}$ The primary hydroxyl groups on the surface of the nanocellulose can be chemically modified to carboxylic acids in a 2,2,6,6-tetramethylpiperidin-1-oxyl (TEMPO) mediated oxidation, which separates cellulose fibrils from their natural bundle configuration to nanocellulose fibers due to repulsion between the negatively charged carboxylic acids functionalities. ${ }^{24}$ Nanocellulose suspensions in water are stable over time with limited formation of aggregates. The unmodified nanocelluloses have a hydrophilic surface covered with hydroxyl groups, while chemically modified nanocellulose can also contain e.g. sulfuric acid derived sulfate. ${ }^{25}$ The highly dispersed nanocellulose fibers are arranged in a fine, fibrous cellulose network containing cavities that include both solvent molecules and the functional groups on the surface of the nanocellulose (Figure 1).

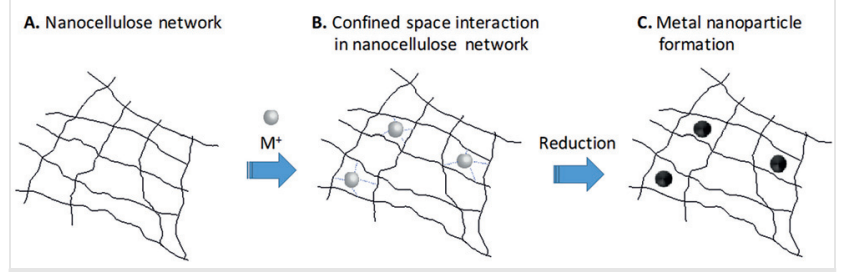

Figure 1 Schematic picture of the formation of nanocellulose supported metal nanoparticles. (A) Nanocellulose network dispersed in aqueous solution. (B) Electrostatic interaction between metal center and oxygen-containing surface moieties. (C) Formation of metal nanoparticles via reduction.

In the confined space of the cavities in the nanocellulose network, the oxygen-containing surface moieties can function as effective metal center stabilizers via the formation of coordinative bonds (Figure 1B), which can be reduced with an external reducing agent (Figure 1C). Several hybrid metal nanoparticle/cellulose materials have been synthesized from transition metals, such as silver, gold, palladium, cadmium, and iron. ${ }^{26,27}$ However, the production of nickelbased nanoparticles supported on nanocellulose and their use in catalytic applications has been scarcer. ${ }^{28}$ In few cases, nickel-based nanoparticles on cellulose have been prepared via the reduction of nickel salts and a reducing agent in the presence of cellulose and show that cellulose can facilitate the formation of small nickel nanoparticles (5-60 nm) in a nanocellulose matrix. ${ }^{29}$ Recently, we generated nickel boride nanoparticles in a solution containing TEMPOoxidized nanocellulose and the result shows that the nanocellulose facilitates the formation of smaller nanoparticles (15-60 nm) compared to similar conditions in water (see Figure 2). ${ }^{29}$ The pre-coordination of $\mathrm{Ni}^{2+}$ ions to the carboxyl groups was confirmed by UV-vis spectroscopy by the appearance of a new shoulder at 390-400 nm upon the addition of nickel chloride to a dispersion of TEMPO-NC (0.01 wt\%), which correlates with the UV maximum at $395 \mathrm{~nm}$ for nickel acetate (Figure 2B). The nickel boride was then
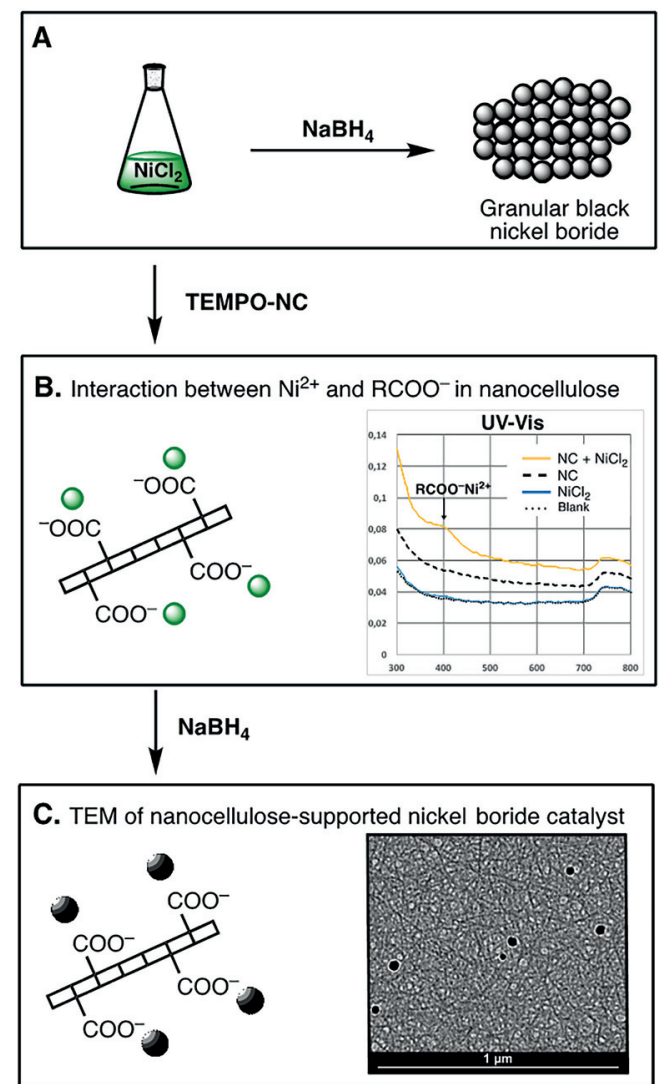

Figure 2 Schematic illustration of using nanocellulose as stabilizing support for nickel boride: (A) Formation of granular black nickel boride. (B) UV-vis spectrum showing the interactions between the carboxyl groups in TEMPO-NC and $\mathrm{Ni}^{2+}$ ions. (C) TEM analysis of the formed nanocellulose-associated nickel boride. 
generated via reduction of nickel chloride with sodium borohydride. The TEM analysis suggests that the nickel boride nanoparticles are embedded in the nanocellulose network, demonstrating its importance as a stabilizer in the formation of the nanoparticles, which in turn open for the use of the entire extensive surface area of the $\mathrm{Ni}$ nanoparticles (Figure 2C). Without the nanocellulose, the nickel boride material is formed as an aggregated black precipitate (Figure 2A), which stresses the importance of the nanocellulose in solution for the formation of smaller and more reactive nanoparticles (Figure 2). Further examples of the supportive nature of the nanocellulose matrix, i.e. to avoid particle aggregation that may limit the reactivity of the particles, can be found in cellulose both present as released/extracted more highly crystalline, individual fibers, or consolidated networks of fibers that can stabilize the nucleation and growth of the particle phase. ${ }^{30}$

To confirm the increased reactivity, the nanocellulosenickel boride nanoparticles were first evaluated in the reduction of nitroarenes (Figure 3 ). ${ }^{29}$ The in situ prepared fiber-associated nanoparticles showed the ability to reduce nitroarenes to anilines in merely $50 \mathrm{~min}$ in water solutions containing the nanocellulose. The low nickel loading $(0.25$ $\mathrm{mol} \%$ ) clearly contrasts previously reported nitroarene reductions promoted by stoichiometric amounts of nickel boride. ${ }^{16,18}$ The enhanced efficacy was verified in the reduction of three different nitro compounds that were reduced in the presence and absence of the TEMPO-NC. The results clearly demonstrate that higher isolated yields (84-95\%) are obtained from the reactions with nanocellulose than the reactions performed only in water (43-28\%) (Figure 3).

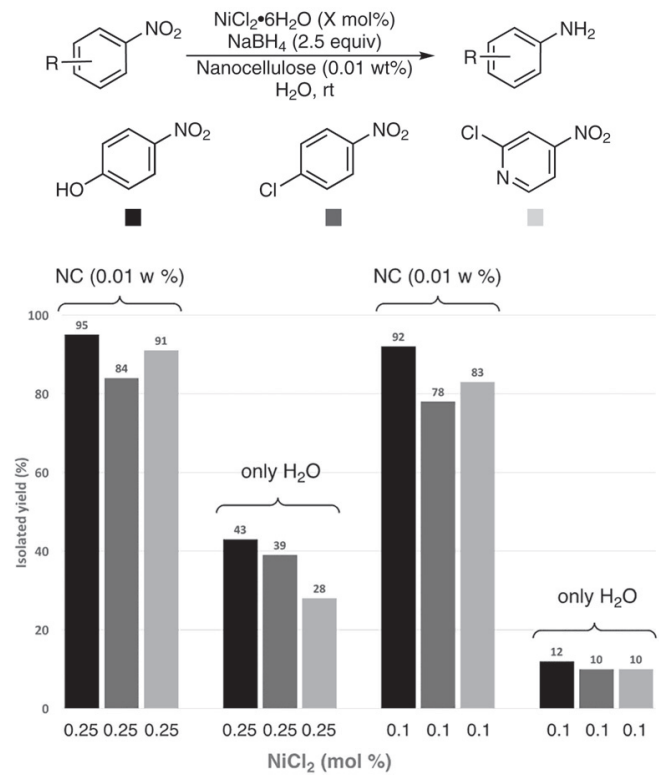

Figure 3 Isolated yields for the reduction of nitro compounds with in situ prepared nickel boride with and without TEMPO-oxidized nanocellulose in water

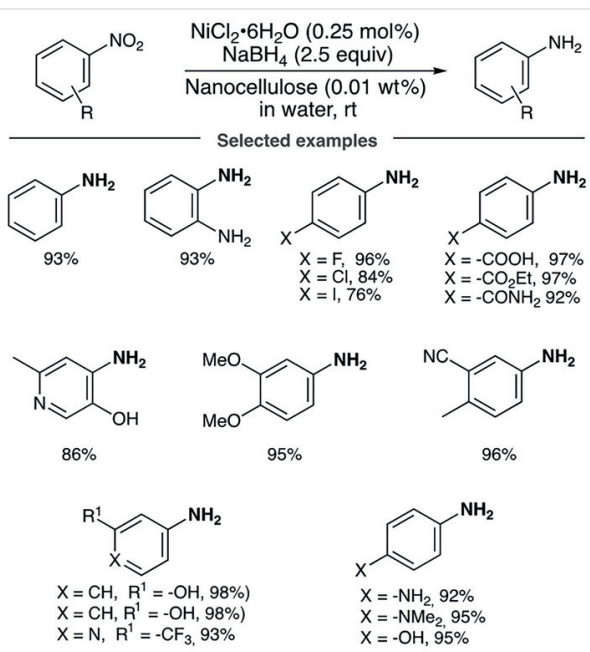

Scheme 2 Reduction of aromatic nitro compounds (reduced group in bold)

Decreasing the amount of nickel chloride ( $0.1 \mathrm{~mol} \%)$ led to an even larger difference in turnover frequency and isolated yields (about 8 times) due to the stabilizing effect of the nanocellulose and that the hybrid nanocellulose-supported nickel boride nanoparticles function as efficient catalyst for the reduction of nitro compounds in water at very low nickel concentrations.

The reaction showed a large substrate scope and about 25 different aromatic and aliphatic nitro compounds were efficiently reduced (see selected examples in Scheme 2).

In order to increase the synthetic utility of the method, two efficient tandem protocols using the hybrid catalyst system were developed. In these protocols, the in situ

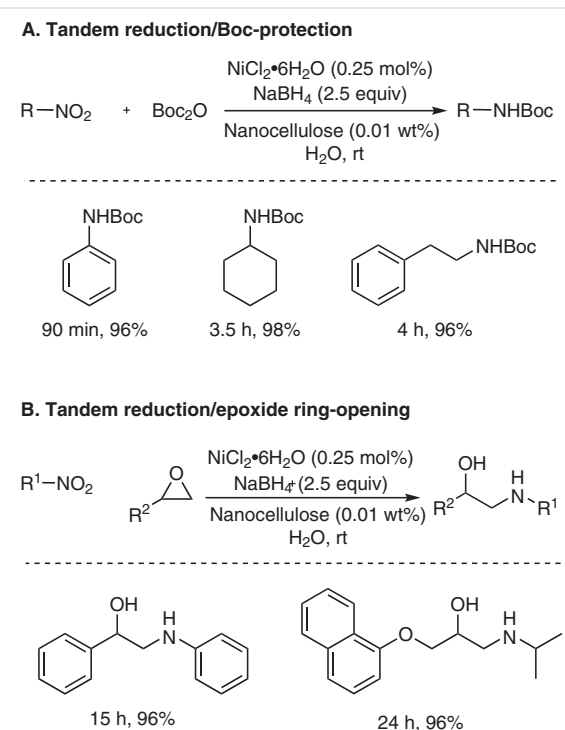

Scheme 3 Nitro group reduction in combination with in situ Boc protection or in situ epoxide ring-opening 
formed amines were either Boc-protected to carbamates or further reacted with an epoxide to yield $\beta$-amino alcohols (Scheme 3). ${ }^{29}$

\section{Azide Reduction - With and Without Nanocellulose Support}

Due to the success of the nanocellulose-nickel boride catalytic system in reducing nitro compounds, ${ }^{29}$ the reactivity of the hybrid catalyst was investigated in the reduction of organic azides. The nickel boride catalytic system was investigated in three different systems; (1) dispersed together with TEMPO-oxidized nancellulose; (2) embedded in a crystalline bacterial nanocellulose support, or (3) as low concentration nickel boride in methanol. Initially, the nickel boride catalyst was prepared in an aqueous solution containing TEMPO-oxidized nanocellulose ${ }^{29}$ and was evaluated in the reduction of benzyl azide. In contrast to the nanocellulose-nickel boride catalyzed reduction of nitro compounds, no rate enhancement was observed in the reduction of the benzyl azide compared to the reaction in deionized water without nanocellulose.

However, our initial investigations showed a high reactivity at low catalyst loading which led us to investigate the potential for the $\mathrm{NiCl}_{2} / \mathrm{NaBH}_{4}$ as a green method with a broad applicability for organic azides reduction (Table 1 ). The reaction was investigated in both aqueous and methanolic solvents using $\mathrm{NiCl}_{2} \cdot 6 \mathrm{H}_{2} \mathrm{O}(0.5-1.5 \mathrm{~mol} \%)$ together with $\mathrm{NaBH}_{4}$ (2.5 equiv), where the sodium borohydride provided both the active catalyst (Ni-B) and at the same time acted as the stoichiometric reducing agent.

In our study on the reduction of aliphatic azides, the formation of a coupling side product was observed for n-octyl azide, ${ }^{31,32}$ which led to lower conversion into the desired amine. Therefore, the reaction with aliphatic azides was performed in the presence of Boc anhydride that traps the formed amine in situ in a tandem reduction-protection reaction to form the carbamate. The nickel boride catalyzed reduction of benzyl azide was active in aqueous solution at low catalyst loading (1.0 mol\%), but at lower catalyst loadings ( $0.25-0.75 \mathrm{~mol} \%)$ led only to a partial conversion. On the other hand, in methanol, which is also referred as a green solvent, ${ }^{33}$ the benzyl azide was completely reduced in 3 hours to the Boc-protected amine employing merely 0.5 mol\% of the nickel catalyst (Table 1). These low catalyst loading represent an important improvement with respect to previously reported transition-metal-catalyzed hydrogenations of azides. ${ }^{34-37} \mathrm{~A}$ series of organic azides were evaluated with the optimized reduction protocol, aliphatic azides showed high conversions and were isolated as the corresponding carbamate after subsequent in situ Boc-protections (Table 2). The reaction resulted also suitable for less accessible azides, and indeed, both secondary and tertiary azides were converted into their reduced products in good
Table 1 Optimization of Catalyst Loading and Solvent

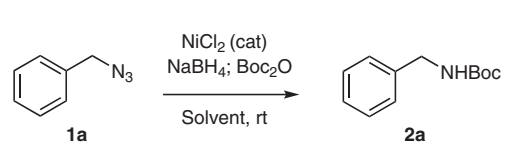

\begin{tabular}{llcll}
\hline Entry & $\mathrm{NiCl}_{2}$ (mol\%) & Time (h) & Solvent & Conversion (\%) [Yield (\%)] \\
\hline 1 & 0.75 & 2 & $\mathrm{H}_{2} \mathrm{O}$ & $86^{\mathrm{b}}$ \\
2 & 0.25 & 6.5 & $\mathrm{H}_{2} \mathrm{O}$ & $36^{\mathrm{b}}$ \\
3 & 1.5 & 1.5 & $\mathrm{H}_{2} \mathrm{O}$ & $100^{\mathrm{b}}$ \\
4 & 1.0 & 3 & $\mathrm{MeOH}$ & $100^{\mathrm{c}}[96]^{\mathrm{d}}$ \\
5 & 0.5 & 16 & $\mathrm{MeOH}$ & $100^{\mathrm{b}}$ \\
6 & 0.5 & 3 & $\mathrm{MeOH}$ & $98^{\mathrm{c}}[89]^{\mathrm{d}}$ \\
7 & 0.25 & 3 & $\mathrm{MeOH}$ & $86^{\mathrm{c}}[80]^{\mathrm{d}}$ \\
\hline
\end{tabular}

a Reaction conditions: $1 \mathrm{a}(0.3 \mathrm{mmol}, 0.15 \mathrm{M}), \mathrm{NiCl}_{2} \cdot 6 \mathrm{H}_{2} \mathrm{O}$ (x mol\%), $\mathrm{NaBH}_{4}$

(3.0 equiv), $\mathrm{Boc}_{2} \mathrm{O}$ (1.5 equiv), degassed solvent, $\mathrm{rt}$.

${ }^{\mathrm{b}}$ Determined by ${ }^{1} \mathrm{H}$ NMR spectroscopy.

c Determined by GC-FID using anisole as internal standard.

${ }^{d}$ Yield determined with GC-FID using anisole as internal standard

yields (Table 2, entries 4 and 5). The azido moiety has orthogonal reactivity and is therefore an attractive strategy to mask reactive amino groups in carbohydrate chemistry or in multistep synthesis. ${ }^{38}$ With this in mind, the benzyl-protected sugar-based azide 1f was evaluated with the optimized reduction conditions. The azide functionality was easily reduced yielding the Boc-protected product $2 \mathbf{f}$ in $74 \%$ yield (Table 2, entry 6 ). In this reaction, the benzyl groups were not affected by the reduction condition suggesting that this method can be a more convenient route to azide reduction than the standard hydrogenation using $\mathrm{H}_{2} / \mathrm{Pd} / \mathrm{C}$.

The more reactive aromatic azides ${ }^{39}$ were also successfully reduced under the reaction conditions (Scheme 4). Remarkably, reduction-sensitive functionalities as nitrile $(\mathbf{2 h})$, carboxylic group (2i), amide (2l), and ester (2o) were all well tolerated by the system. The azide was chemoselectively reduced even in the presence of the benzyl ether group, which is often cleaved-off via transition-metalcatalyzed hydrogenation. ${ }^{40}$

A modified protocol was developed in order to achieve chemoselectivity in aromatic compounds containing halogen substituents on the aromatic ring. 1-Azido-2-chlorobenzene (1p) was successfully reduced to the corresponding aniline when the reaction temperature was lowered to $20^{\circ} \mathrm{C}$, and under these conditions the dehalogenation side reaction was completely suppressed. Replacing the chloro with the iodo substituent, compound $\mathbf{1 n}$, the chemoselectivity was decreased leading to increased formation of aniline. Depriving the system of the necessary reductant by lowering the equivalents of sodium borohydride $(0.85$ equiv) prevented the over-reduction of the 4-iodoaniline to aniline, leading to the formation of the product in $84 \%$ yield at $-20^{\circ} \mathrm{C}$. Unfortunately, attempts to obtain similar chemoselectivity in the presence of a terminal olefin [1-azido-4- 
Table 2 Tandem Reduction and Boc-Protection of Aliphatic Azides with Nickel Boride Catalyst ${ }^{a}$

$$
\underset{1}{\mathrm{R}-\mathrm{N}_{3}} \stackrel{\substack{\mathrm{NiCl}_{2} \text { (cat) } \\ \mathrm{NaBH}_{4} ; \mathrm{Boc}_{2} \mathrm{O}}}{\mathrm{MeOH}, \mathrm{rt}} \underset{2}{\mathrm{R}-\mathrm{NHBoc}}
$$

Entry

a Reaction conditions: azide (0.3-0.6 mmol, $0.15 \mathrm{M}), \mathrm{NiCl}_{2} \cdot 6 \mathrm{H}_{2} \mathrm{O}(0.5$ mol\%), $\mathrm{NaBH}_{4}$ (2.5 equiv), $\mathrm{Boc}_{2} \mathrm{O}$ (1.2 equiv), degassed $\mathrm{MeOH}, \mathrm{rt}, 3 \mathrm{~h}$.

${ }^{\mathrm{b}}$ Isolated yield.

c $1.0 \mathrm{~mol} \%$ catalyst loading used.

d 1.5 mol\% catalyst loading used.

(vinyloxy)benzene] resulted in a mixture of products mainly containing the target compound [4-(vinyloxy)aniline] together with the final aniline with the double bond reduced.

In an effort to disclose the synthetic appeal of the reduction system, a tandem reaction was devised involving the synthesis of the azide (1a) starting from benzyl bromide, followed by the reduction and Boc-protection of the newly formed amine in a one-pot protocol leading to a satisfying $86 \%$ overall yield (Scheme 5 ).

Immobilizing the metal nanoparticle on a solid support is an often-used strategy to stabilize or enhance the reactivity of the catalyst. Embedding the catalyst on a heterogeneous support can also enable an easy recover step and thus the removal of the catalyst from the reaction mixture with the possibility to reuse it for a second cycle. To further simplify the reaction protocol, the active in situ generated
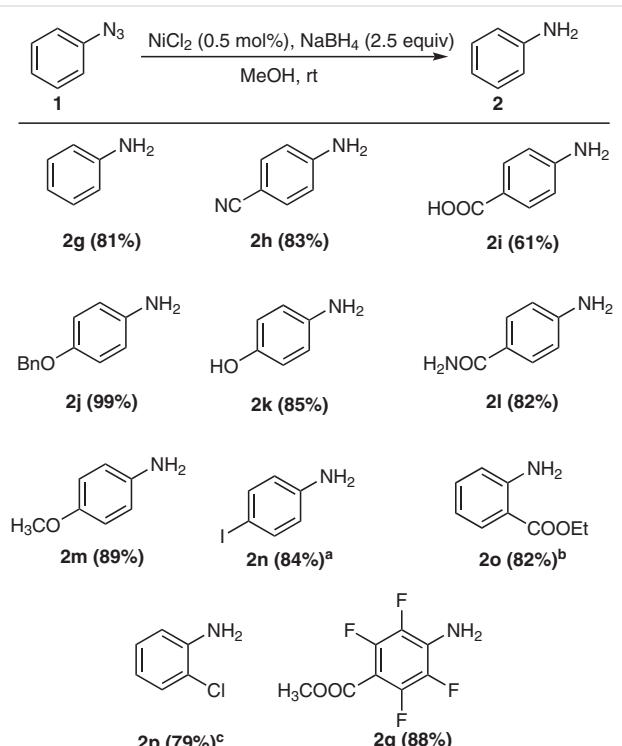

Scheme 4 Reduction of more reactive azides and halo-substituted azides. Reagents and conditions: azide (0.15-0.6 mmol, 0.15 M), $\mathrm{NiCl}_{2} \cdot 6 \mathrm{H}_{2} \mathrm{O}$ (0.5 mol\%), $\mathrm{NaBH}_{4}$ (2.5 equiv), degassed $\mathrm{MeOH}, \mathrm{rt}, 3 \mathrm{~h}$. ${ }^{a} \mathrm{t}=-20^{\circ} \mathrm{C} ; 0.85$ equiv $\mathrm{NaBH}_{4} \cdot{ }^{\mathrm{b}} \mathrm{EtOH}$ used as the solvent. ${ }^{\mathrm{c}} \mathrm{t}=-20^{\circ} \mathrm{C}$.

catalyst was loaded onto a support ${ }^{25}$ that allowed the removal of the catalyst by filtration and, at the same time, provided a practical solution for recycling the catalyst. In line with recently publish work of our group, ${ }^{29}$ the support of choice was bacterial crystalline nanocellulose (BNC), which represent a versatile support that offers high fibril uniformity and mechanical stability (Young's modulus > $100 \mathrm{GPa}),{ }^{30}$ high surface area $\left(>200 \mathrm{~m}^{2} / \mathrm{g}\right),{ }^{41}$ together with being a bio-sourced, biodegradable, and non-toxic material already used to stabilize different types of metal nanoparticles. ${ }^{27,42}$ In comparison with the TEMPO-oxidized cellulose from natural forest material that require extensive oxidation to obtain the 3-5 nm fibrils), ${ }^{43}$ the BNC is acid extracted from the Acetobacter xylinum pellicle as ca. $40-50 \mathrm{~nm}$ ribbons containing the tightly organized and highly crystalline $(>80 \%)$ Cellulose I crystals of typical length $>2-3 \mu \mathrm{m}$ (Figure 4b). ${ }^{44}$ A sample of bacterial nanocellulose was dipped into an aqueous solution of the $\mathrm{Ni}(\mathrm{II})$ salt, the excess of water was removed and upon lyophilization the $\mathrm{NiCl}_{2} \cdot 6 \mathrm{H}_{2} \mathrm{O}$ functionalized material was obtained.

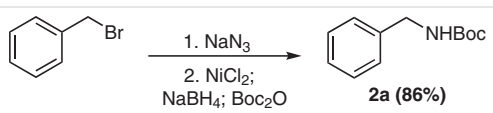

Scheme 5 Procedure for the one-pot synthesis, reduction, and Bocprotection of benzyl azide 

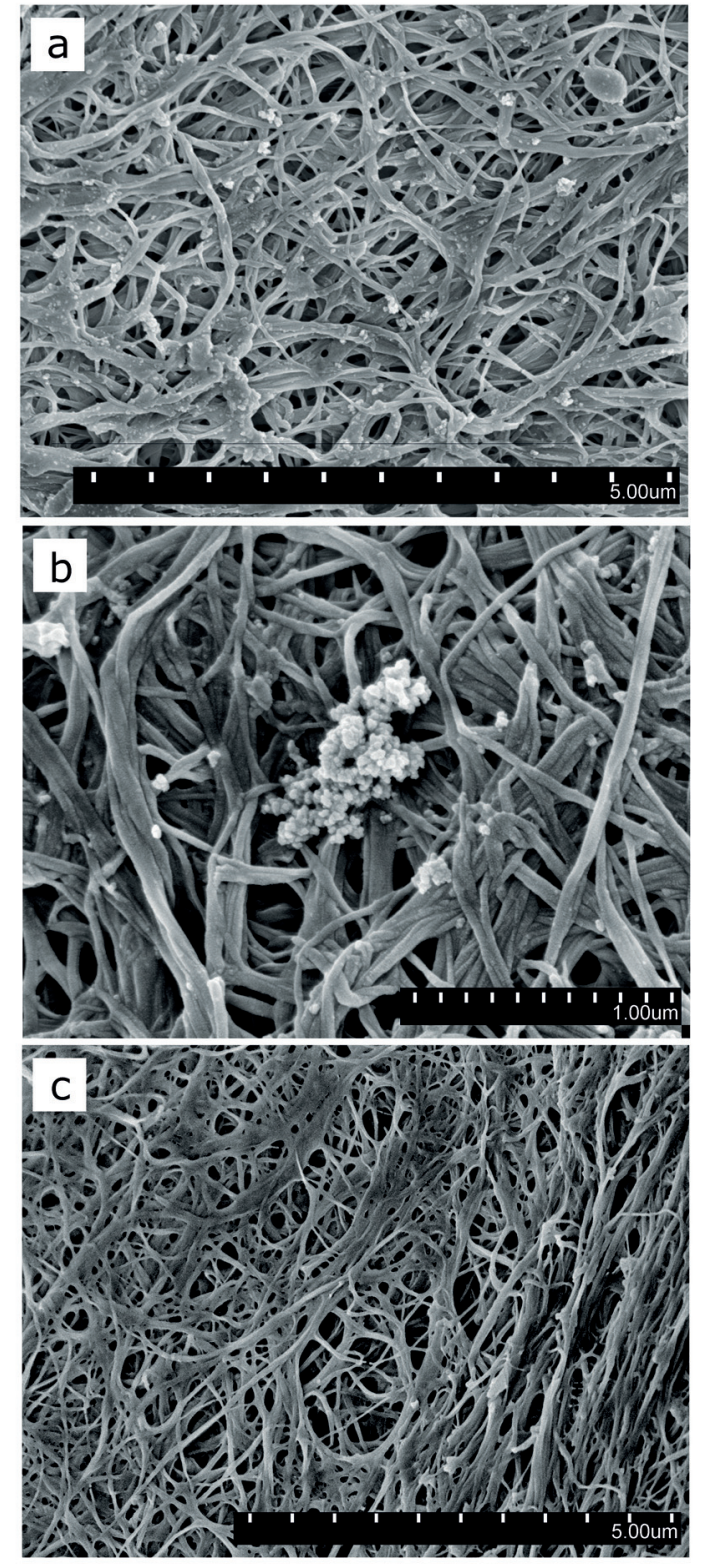

Figure 4 SEM images of Ni-B nanoparticle supported on bacterial crystalline nanocellulose. (a) Overview of the functionalized support (scale bar $5.00 \mu \mathrm{m}$ ). Metal-NPs appears as bright spots on the nanocellulose material. (b) $30.0 \mathrm{k}$ magnification on NPs aggregates around nanocellulose fibrils (scale bar $1.00 \mu \mathrm{m}$ ). (c) Bacterial crystalline nanocellulose prior to functionalization (scale bar $5.00 \mu \mathrm{m}$ ).

The material was added to a solution of sodium borohydride in order to generate the active NiB-BNC catalyst. Scanning electron microscopy (SEM) analyses were carried out on the obtained functionalized solid support in order to investigate the interaction between the catalyst and its support. As anticipated, the in situ obtained Ni-B, formed spherical nanoparticles (NPs) associated to the nanofibrils of the cellulose. It was also visible that the nanoparticles vary in dimensions with the diameters of the NPs ranging between 10 and $100 \mathrm{~nm}$, with a tendency to form larger aggregates (Figure 4 ).

The new NiB-BNC material was used in the reduction of the azide $\mathbf{1} \mathbf{j}$ under the usual reaction conditions, but with the $\mathrm{Ni}(\mathrm{II})$ salt loaded on the nanocellulose support, which upon addition of sodium borohydride is converted into the active catalyst Ni-B (see supporting information, Figure $\mathrm{S} 1$ ). After completion of the reaction, the catalyst was conveniently filtered off and reused for a further two cycles providing satisfying conversion. As noted elsewhere, ${ }^{19}$ the exposure of Ni-B catalyst to air lead to a drop of its catalytic performances and this observation was confirmed in our experiments (Figure 5).

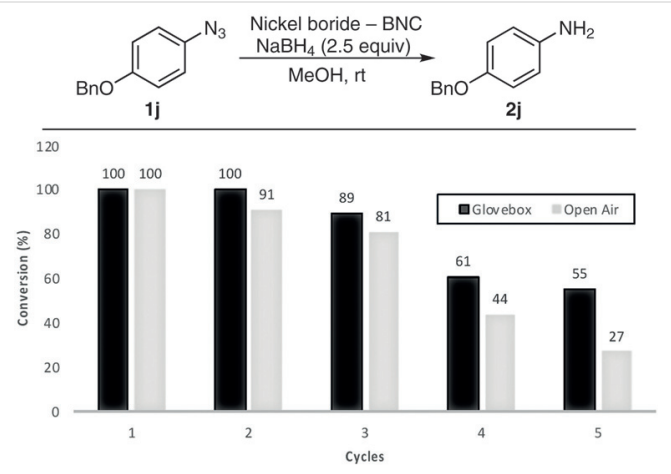

Figure 5 Reduction of $\mathbf{1} \mathbf{j}$ using $\mathrm{NiCl}_{2}$ loaded on nanocellulose. Reagents and conditions: azide $(0.18 \mathrm{mmol}, 0.18 \mathrm{M}), \mathrm{NiCl}_{2} \cdot 6 \mathrm{H}_{2} \mathrm{O}$ (1.0 mol\%), $\mathrm{NaBH}_{4}$ (2.5 equiv), degassed $\mathrm{MeOH}$, rt. At completion of the reaction, the mixture is filtered off and the catalyst support washed and reused for the next cycle. Reaction times are: $20 \mathrm{~min}, 25 \mathrm{~min}$, and $33 \mathrm{~min}$, $60 \mathrm{~min}, 120 \mathrm{~min}$ for cycles 1, 2, 3, 4 and 5, respectively.

In fact, the catalyst was recyclable only for a limited number of cycles (3) after which, the catalytic activity sharply decreased. Even when the reduction reaction was conducted in an oxygen free atmosphere, as in a glovebox, the conversion observed after repeated cycles were substantially lower. The mother liquors of the 1 st and the 2 nd cycle of a recycling experiment were collected and analyzed via ICP-OES to investigate the amount of leached nickel boride catalyst. The analyses showed that in the first cycle, $3.9 \%$ of the nickel catalyst was leached into the solution, whereas in the second cycle only $0.8 \%$ was leached. We hypothesize that the higher observed amount of nickel in the 1 st cycle is due to a leaching of the $\mathrm{NiCl}_{2}$ precatalyst during its formation which makes it more loosely bound to the cellulose support.

\section{Conclusion}

The developed procedure enlarges the portfolio of azide-reduction protocols providing organic chemists with a practically convenient method that is superior, or comple- 
mentary, to already existing protocols present in the literature to perform the azide to amine conversion via hydrogenation. ${ }^{32,35,37,45}$ With the aim of designing a sustainable reaction, the catalyst loading was successfully lowered to 0.5 mol\%, representing a substantial improvement on respect of already existing methodologies catalyzed by cheap and abundant transition metal. ${ }^{36,37}$ The reaction system was proved to be general for both aliphatic and aromatic azide and a wide range of azides were tested in an attempt to highlight the limits of the reaction system as well as its functional group tolerability. The functionalization of the solid support (i.e., crystalline nanocellulose) with the catalyst's precursor, further enhanced the operational simplicity of the reaction system. In addition, a one-pot synthesis of the Boc-protected benzylamine, starting from benzyl bromide, was successfully carried out.

All reagents were obtained from commercial sources and used without further purification. All solvents were purified and dried according to standard methods prior to use, unless stated otherwise. Degassed solvents were obtained by bubbling the solvent with inert gas through a needle. TLC was performed using 60 mesh silica gel plates visualized with short-wavelength UV light $(254 \mathrm{~nm})$. Silica gel 60 (200-300 mesh) was used for column chromatography. The surface morphology of the catalyst loaded onto the support was analyzed using a Hitachi S-4800 field emission scanning electron microscope (FESEM). A voltage of $3 \mathrm{kV}$ and a current of $10 \mu \mathrm{A}$ were used. The lyophilized materials were sputtered with a palladium/platinum (Pt/Pd) target in an Agar High Resolution Sputter Coater (model 208RH). The sputtering time for all samples was $45 \mathrm{~s}$ proving an estimated conductive layer of 1-2 nm. ICP-OES analyses were run with a Thermo Scientific iCAP 6000 series instrument and standard Ni solutions were prepared and measured prior to the real analyses to obtain the calibration curve. A Bruker Ascend 400 spectrometer $(400 \mathrm{MHz})$ or Bruker Avance DMX $500(500 \mathrm{MHz})$ spectrometer was used for the recording of ${ }^{1} \mathrm{H}$, ${ }^{13} \mathrm{C}$, and ${ }^{19} \mathrm{~F}$ NMR spectra. Proton chemical shifts are reported relative to TMS with residual undeuterated $\mathrm{CHCl}_{3}(\delta=7.26)$, DMSO- $d_{6}(\delta=2.50)$, and methanol- $d_{4}(\delta=3.31)$ as internal standards. ${ }^{13} \mathrm{C}$ chemical shifts are reported relative to TMS with $\mathrm{CDCl}_{3}(\delta=77.16)$, DMSO- $d_{6}(\delta=$ 39.52), or methanol- $d_{4}(\delta=49.0)$ as internal standards.

\section{Tandem Reduction and Boc-Protection of Aliphatic Azido Com- pounds; General Procedure A (GPA)}

To a 5-mL sealed vial equipped with a magnetic stir bar, a solution containing azido compound ( 1 equiv, $0.15 \mathrm{mM}$ ) in deoxygenated $\mathrm{MeOH}, \mathrm{NiCl}_{2} \cdot 6 \mathrm{H}_{2} \mathrm{O}$ (0.5 mol\%), $\mathrm{Boc}_{2} \mathrm{O}$ (1.1 equiv), and $\mathrm{NaBH}_{4}(2.5$ equiv) were added. The mixture was stirred at $\mathrm{rt}$ for $3 \mathrm{~h}$ protected from light. After completion of the reaction, the crude obtained upon solvent removal under reduced pressure was purified via flash column chromatography (petroleum ether/EtOAc) to afford the pure product. All compounds synthesized herein are known in the literature. Proof of purity and identity was obtained by ${ }^{1} \mathrm{H},{ }^{13} \mathrm{C}$, and ${ }^{19} \mathrm{~F}$ NMR spectroscopy.

\section{Reduction of Aromatic Azido Compounds; General Procedure B (GPB)}

To a 5-mL sealed vial equipped with a magnetic stir bar, a solution containing azido compound ( 1 equiv, $0.15 \mathrm{mM}$ ) in deoxygenated
$\mathrm{MeOH}, \mathrm{NiCl}_{2} \cdot 6 \mathrm{H}_{2} \mathrm{O}(0.5 \mathrm{~mol} \%)$, and $\mathrm{NaBH}_{4}$ (2.5 equiv) were added. The mixture was stirred at $\mathrm{rt}$ for $3 \mathrm{~h}$ protected from light. After completion of the reaction, the crude obtained upon solvent removal under reduced pressure, was re-dissolved in water and extracted with $\mathrm{Et}_{2} \mathrm{O}$ or EtOAc, leaving the catalyst in the aqueous phase. The organic layer was dried $\left(\mathrm{Na}_{2} \mathrm{SO}_{4}\right)$, and the pure product was obtained upon in vacuo solvent removal. All compounds were characterized by ${ }^{1} \mathrm{H}$ and ${ }^{13} \mathrm{C}$ NMR spectroscopy.

\section{Synthesis of Substituted Aromatic Azido Compounds $;{ }^{46}$ General Procedure C (GPC)}

To a methanolic solution of the boronic acid (1.0 equiv, $0.1 \mathrm{M}$ ) were added $\mathrm{NaN}_{3}$ (1.5 equiv) and $\mathrm{Cu}(\mathrm{OAc})_{2}(0.05-0.1$ equiv). The solution was stirred for $24-48 \mathrm{~h}$ at $30{ }^{\circ} \mathrm{C}$ under air, protected from the light. The solvent was then removed, and the crude was taken up with $\mathrm{H}_{2} \mathrm{O}$ and extracted with $\mathrm{Et}_{2} \mathrm{O}$. The organic layer was dried $\left(\mathrm{Na}_{2} \mathrm{SO}_{4}\right)$, and the pure product was either obtained at this stage or after a further purification by flash column chromatography. All compounds were characterized by ${ }^{1} \mathrm{H}$ and ${ }^{13} \mathrm{C}$ NMR spectroscopy.

\section{Catalyst Recycling Experiment; General Procedure D}

In a typical experiment, bacterial crystalline nanocellulose (ca. 3.5 $\mathrm{mg}$ ), was soaked for $3 \mathrm{~min}$ in a $10 \mathrm{mM}$ aq solution of $\mathrm{NiCl}_{2} \cdot 6 \mathrm{H}_{2} \mathrm{O}$. The new material was then transferred into a vial and $\mathrm{H}_{2} \mathrm{O}$ removed via lyophilization. The amount of the nickel salt loaded was obtained by weighing the cellulose support after the functionalization [average $\mathrm{NiCl}_{2} \cdot 6 \mathrm{H}_{2} \mathrm{O}$ loading: $16.4( \pm 3.0) \mathrm{wt} \%$. The functionalized $\mathrm{NiCl}_{2}$-nanocellulose was subsequently transferred into a Biotage ${ }^{\circledR} 10-\mathrm{mL}$ reactor vial with PTFE frit equipped with stir bar and a rubber septum under inert atmosphere. Compound $\mathbf{1 j}$ ( 1 equiv, $0.15 \mathrm{mM}$ ) in deoxygenated $\mathrm{MeOH}$ and $\mathrm{NaBH}_{4}$ (2.5 equiv) were added. The mixture was stirred at $\mathrm{rt}$ and upon completion of the reaction, the solution was worked up as in general procedure B, whilst the catalyst support was filtered-off, washed with $\mathrm{MeOH}$ and re-used in the next reaction cycle. The conversion of the starting material was obtained via ${ }^{1} \mathrm{H}$ NMR analysis.

\section{One-pot procedure for the synthesis of tert-butyl benzylcarba-} mate (2a)

In a $5 \mathrm{~mL}$ sealed vial equipped with a magnetic stir bar, deoxygenated methanol ( $3 \mathrm{~mL}$ ), $\mathrm{NaN}_{3}$ ( $38 \mathrm{mg}, 0.58 \mathrm{mmol}, 2.2$ equiv) and benzyl bromide ( $45 \mathrm{mg}, 0.26 \mathrm{mmol}, 1$ equiv), were added. The reaction mixture was stirred at $55^{\circ} \mathrm{C}$ for 3 hours protected from light until completion of the substitution reaction as observed by TLC analysis. The reaction mixture was let reach room temperature before adding a solution of $\mathrm{NiCl} 2$ in degassed methanol ( $0.0013 \mathrm{mmol}, 32 \mu \mathrm{L}, 42 \mathrm{mM})$, Boc anhydride (69 mg, $0.30 \mathrm{mmol}, 1.2$ equiv) and $\mathrm{NaBH}_{4}(25 \mathrm{mg}, 0.65 \mathrm{mmol}$, 2.5 equiv). The reaction was then stirred for further 3 hours at room temperature. After completion of the reaction, the crude obtained upon solvent removal under reduced pressure was purified via flash column chromatography (silica gel, petroleum ether/EtOAc, 10:1) to afford the pure product as a colorless oil in an overall $86 \%$ yield.

${ }^{1} \mathrm{H} \mathrm{NMR}\left(400 \mathrm{MHz}, \mathrm{CDCl}_{3}\right.$ ): $\delta=7.34-7.25$ (br, $5 \mathrm{H}$ ), $4.88(\mathrm{~s}, 1 \mathrm{H}, \mathrm{NH}$ ), $4.30(\mathrm{~s}, 2 \mathrm{H}), 1.46(\mathrm{~s}, 9 \mathrm{H})$.

${ }^{13} \mathrm{C}$ NMR $\left(100 \mathrm{MHz}, \mathrm{CDCl}_{3}\right): \delta=156.0,139.1,128.7,127.6,127.4,79.6$, 44.8, 28.5.

\section{tert-Butyl Benzylcarbamate (2a)}

The compound was obtained according to GPA using azido compound 1a (51 mg, $0.4 \mathrm{mmol}, 1$ equiv), $\mathrm{NiCl}_{2}(47 \mu \mathrm{L}, 42 \mathrm{mM}, 0.5 \mathrm{~mol} \%), \mathrm{Boc}_{2} \mathrm{O}$ (95 mg, $0.44 \mathrm{mmol}, 1.1$ equiv), and $\mathrm{NaBH}_{4}$ (41 mg, $1.1 \mathrm{mmol}, 2.8$ 
equiv). The pure product was obtained after flash column chromatography (silica gel, petroleum ether/EtOAc, 10:1) as a colorless oil (64 $\mathrm{mg}, 84 \%$ yield).

${ }^{1} \mathrm{H}$ NMR $\left(400 \mathrm{MHz}, \mathrm{CDCl}_{3}\right): \delta=7.34-7.25(\mathrm{br}, 5 \mathrm{H}), 4.88(\mathrm{~s}, 1 \mathrm{H}, \mathrm{NH})$, $4.30(\mathrm{~s}, 2 \mathrm{H}), 1.46(\mathrm{~s}, 9 \mathrm{H})$

${ }^{13} \mathrm{C} \mathrm{NMR}\left(100 \mathrm{MHz}, \mathrm{CDCl}_{3}\right): \delta=156.0,139.1,128.7,127.6,127.4,79.6$, $44.8,28.5$.

\section{tert-Butyl Octylcarbamate (2b)}

The compound was obtained according to GPA using azido compound 1 b $\left(57 \mathrm{mg}, 0.3 \mathrm{mmol}, 1\right.$ equiv), $\mathrm{NiCl}_{2}$ ( $100 \mu \mathrm{L}, 42 \mathrm{mM}, 1.0 \mathrm{~mol} \%$ ), $\mathrm{Boc}_{2} \mathrm{O}$ (105 mg, $0.48 \mathrm{mmol}, 1.3$ equiv), and $\mathrm{NaBH}_{4}(40 \mathrm{mg}, 1.0 \mathrm{mmol}$, 2.9 equiv). The pure product was obtained after flash column chromatography (silica gel, petroleum ether/ $\mathrm{Et}_{2} \mathrm{O}, 90: 10$ ) as a colorless oil (69 $\mathrm{mg}, 82 \%$ yield).

${ }^{1} \mathrm{H} \mathrm{NMR}\left(\mathrm{CDCl}_{3}, 400 \mathrm{MHz}\right): \delta=4.50(\mathrm{~s}, 1 \mathrm{H}, \mathrm{NH}), 3.07(\mathrm{t}, J=6.93 \mathrm{~Hz}, 2$ $\left.\mathrm{H}, \mathrm{CH}_{2} \mathrm{~N}\right), 1.42\left(\mathrm{~s}, 11 \mathrm{H}, t-\mathrm{Bu}+\mathrm{CH}_{2}\right), 1.26(\mathrm{~s}, 10 \mathrm{H}), 2.93(\mathrm{t}, J=6.52 \mathrm{~Hz}, 3$ $\mathrm{H}, \mathrm{CH}_{3} \mathrm{CH}_{2}$ ).

${ }^{13} \mathrm{C}\left\{{ }^{1} \mathrm{H}\right\}$ NMR $\left(\mathrm{CDCl}_{3}, 100 \mathrm{MHz}\right): \delta=156.1,79.1,40.9,31.9,30.2,29.4$, $29.3,28.5,26.9,22.7,14.2$.

\section{tert-Butyl \{2-[2-(2-Hydroxyethoxy)ethoxy]ethyl\}carbamate (2c)}

The compound was obtained according to GPA using azido compound 1c (105 mg, $0.6 \mathrm{mmol}, 1$ equiv), $\mathrm{NiCl}_{2}(70 \mu \mathrm{L}, 42 \mathrm{mM}, 0.5 \mathrm{~mol} \%), \mathrm{Boc}_{2} \mathrm{O}$ (150 mg, $0.69 \mathrm{mmol}, 1.2$ equiv), and $\mathrm{NaBH}_{4}$ (56 mg, $1.5 \mathrm{mmol}, 2.5$ equiv). The pure product was obtained after flash column chromatography (silica gel, $\mathrm{CH}_{2} \mathrm{Cl}_{2} / \mathrm{MeOH} 98: 2$ ) as a colorless oil (124 mg, 83\% yield).

${ }^{1} \mathrm{H}$ NMR $\left(\mathrm{CDCl}_{3}, 400 \mathrm{MHz}\right): \delta=5.27(\mathrm{~s}, 1 \mathrm{H}, \mathrm{NH}), 4.88(\mathrm{~s}, 1 \mathrm{H}, \mathrm{OH})$, 3.66-3.64 (m, $2 \mathrm{H}), 3.56-3.50(\mathrm{~m}, 6 \mathrm{H}), 3.46(\mathrm{t}, J=5.13 \mathrm{~Hz}, 2 \mathrm{H}$, $\left.\mathrm{CH}_{2} \mathrm{OH}\right), 3.23-3.21\left(\mathrm{~m}, 2 \mathrm{H}, \mathrm{CH}_{2} \mathrm{~N}\right), 1.35(\mathrm{~s}, 9 \mathrm{H}, t-\mathrm{Bu})$.

${ }^{13} \mathrm{C}\left\{{ }^{1} \mathrm{H}\right\} \mathrm{NMR}\left(\mathrm{CDCl}_{3}, 100 \mathrm{MHz}\right): \delta=156.1,79.1,72.6,70.30,70.2,61.5$, 40.3, 28.4 .

\section{tert-Butyl Cyclohexylcarbamate (2d)}

The compound was obtained according to GPA using azido compound 1d (42 mg, $0.3 \mathrm{mmol}, 1$ equiv), $\mathrm{NiCl}_{2}$ ( $\left.70 \mu \mathrm{L}, 42 \mathrm{mM}, 1.0 \mathrm{~mol} \%\right), \mathrm{Boc}_{2} \mathrm{O}$ (102 mg, $0.47 \mathrm{mmol}, 1.4$ equiv), and $\mathrm{NaBH}_{4}(37 \mathrm{mg}, 1.0 \mathrm{mmol}, 2.9$ equiv). The pure product was obtained after flash column chromatography (silica gel, petroleum ether/EtOAc 10:1) as colorless oil (51 mg, $76 \%$ yield).

${ }^{1} \mathrm{H} \mathrm{NMR}\left(\mathrm{CDCl}_{3}, 400 \mathrm{MHz}\right): \delta=4.39(\mathrm{br}, 1 \mathrm{H}, \mathrm{NH}), 3.38(\mathrm{~s}, 1 \mathrm{H}), 1.90-$ $1.87(\mathrm{~m}, 2 \mathrm{H}), 1.70-1.64(\mathrm{~m}, 2 \mathrm{H}), 1.58-1.55(\mathrm{~m}, 1 \mathrm{H}), 1.47$ (s, $9 \mathrm{H}, t-$ $\mathrm{Bu}), 1.29-1.19(\mathrm{~m}, 2 \mathrm{H}), 1.16-1.02(\mathrm{~m}, 3 \mathrm{H})$.

${ }^{13} \mathrm{C}\left\{{ }^{1} \mathrm{H}\right\} \operatorname{NMR}\left(\mathrm{CDCl}_{3}, 100 \mathrm{MHz}\right): \delta=155.4,79.1,49.6,33.7,28.6,25.7$, 25.0.

\section{tert-Butyl Adamantan-1-ylcarbamate (2e)}

The compound was obtained according to GPA using azido compound 1e (60 mg, $0.3 \mathrm{mmol}, 1$ equiv), $\mathrm{NiCl}_{2}(120 \mu \mathrm{L}, 42 \mathrm{mM}, 1.5 \mathrm{~mol} \%), \mathrm{Boc}_{2} \mathrm{O}$ (92 mg, $0.42 \mathrm{mmol}, 1.3$ equiv), and $\mathrm{NaBH}_{4}$ (32 mg, $0.85 \mathrm{mmol}, 2.5$ equiv). The pure product was obtained after flash column chromatography (silica gel, petroleum ether/ $\mathrm{Et}_{2} \mathrm{O} 95: 5$ ) as a white precipitate (47 mg, 55\% yield).

${ }^{1} \mathrm{H} \mathrm{NMR}\left(\mathrm{CDCl}_{3}, 400 \mathrm{MHz}\right): \delta=4.37(\mathrm{br}, 1 \mathrm{H}, \mathrm{NH}), 2.05(\mathrm{~s}, 3 \mathrm{H}), 1.91(\mathrm{~d}$, $J=2.3 \mathrm{~Hz}, 6 \mathrm{H}), 1.65$ (s, $6 \mathrm{H}), 1.43(\mathrm{~s}, 9 \mathrm{H}, t-\mathrm{Bu})$.

${ }^{13} \mathrm{C}\left\{{ }^{1} \mathrm{H}\right\} \operatorname{NMR}\left(\mathrm{CDCl}_{3}, 100 \mathrm{MHz}\right): \delta=154.2,78.7,50.5,42.1,36.5,29.6$, 28.6.

\section{Boc-Protected Methyl 6-Amino-2,3,4-tri-O-benzyl-6-deoxy- $\alpha$-D-} glucopyranoside (2f)

The compound was obtained according to GPA using azido compound 1f (143 mg, $0.3 \mathrm{mmol}, 1$ equiv), $\mathrm{NiCl}_{2}(69 \mu \mathrm{L}, 42 \mathrm{mM}, 1.0 \mathrm{~mol} \%), \mathrm{Boc}_{2} \mathrm{O}$ (79 mg, $0.36 \mathrm{mmol}, 1.2$ equiv), and $\mathrm{NaBH}_{4}(28 \mathrm{mg}, 0.74 \mathrm{mmol}, 2.5$ equiv). The pure product was obtained after flash column chromatography (silica gel, petroleum ether $/ \mathrm{CH}_{2} \mathrm{Cl}_{2} /$ EtOAc 8:1:1 $\rightarrow$ 4:1:1; $R_{f}$ 0.44, petroleum ether $\left./ \mathrm{CH}_{2} \mathrm{Cl}_{2} / \mathrm{EtOAc} 4: 1: 1\right)$ as colorless oil $(120 \mathrm{mg}$, $73 \%$ yield).

${ }^{1} \mathrm{H}$ NMR $\left(\mathrm{CDCl}_{3}, 400 \mathrm{MHz}\right): \delta=7.34-7.42(\mathrm{~m}, 15 \mathrm{H}, \mathrm{Ar}), 5.04(\mathrm{~d}, J=$ $\left.10.8 \mathrm{~Hz}, 1 \mathrm{H}, \mathrm{CH}_{2} \mathrm{Ar}\right), 4.67-4.91\left(\mathrm{~m}, 6 \mathrm{H}, \mathrm{CH}_{2} \mathrm{Ar}+\mathrm{NH}\right), 4.59(\mathrm{~d}, J=3.4$ $\mathrm{Hz}, 1 \mathrm{H}, \mathrm{H}-1), 4.05(\mathrm{t}, J=9.24 \mathrm{~Hz}, 1 \mathrm{H}), 3.71-3.74(\mathrm{~m}, 1 \mathrm{H}), 3.52-3.56$ $(\mathrm{m}, 2 \mathrm{H}), 3.40\left(\mathrm{~s}, 5 \mathrm{H}, \mathrm{CH}+\mathrm{OCH}_{3}\right), 1.48(\mathrm{~s}, 9 \mathrm{H}, t-\mathrm{Bu})$.

${ }^{13} \mathrm{C}\left\{{ }^{1} \mathrm{H}\right\}$ NMR $\left(\mathrm{CDCl}_{3}, 100 \mathrm{MHz}\right): \delta=155.8,138.7,138.2,138.1,128.6$, $128.51,128.50,128.4,128.2,128.1,128.0,127.9,127.7,98.0,82.0$, $80.1,79.3,78.6,75.9,75.2,73.4,69.4,55.1,41.0,28.6$.

\section{Aniline (2g)}

The compound was obtained according to GPB using azido compound 1 g ( $65 \mu \mathrm{L}, 0.6 \mathrm{mmol}, 1$ equiv), $\mathrm{NiCl}_{2}(70 \mu \mathrm{L}, 42 \mathrm{mM}, 0.5 \mathrm{~mol} \%)$, and $\mathrm{NaBH}_{4}(64 \mathrm{mg}, 1.7 \mathrm{mmol}, 2.8$ equiv) to give the product as colorless oil (45 mg, 81\% yield).

${ }^{1} \mathrm{H} \mathrm{NMR}\left(\mathrm{CDCl}_{3}, 400 \mathrm{MHz}\right): \delta=7.12(\mathrm{t}, J=7.56 \mathrm{~Hz}, 2 \mathrm{H}), 6.73(\mathrm{t}, J=7.10$ $\mathrm{Hz}, 1 \mathrm{H}), 6.64$ (d, J = 8.28 Hz, $2 \mathrm{H}), 3.5(\mathrm{~s}, 2 \mathrm{H}, \mathrm{NH})$.

${ }^{13} \mathrm{C}\left\{{ }^{1} \mathrm{H}\right\} \operatorname{NMR}\left(\mathrm{CDCl}_{3}, 100 \mathrm{MHz}\right): \delta=146.5,129.4,118.7,115.2$.

\section{4-Aminobenzonitrile (2h)}

The compound was obtained according to GPB using azido compound 1h (22 mg, $0.15 \mathrm{mmol}, 1$ equiv), $\mathrm{NiCl}_{2}(25 \mu \mathrm{L}, 42 \mathrm{mM}, 0.5 \mathrm{~mol} \%)$, and $\mathrm{NaBH}_{4}$ (17 mg, $0.45 \mathrm{mmol}, 2.9$ equiv) to give the product as paleyellow oil ( $15 \mathrm{mg}, 83 \%$ yield).

${ }^{1} \mathrm{H} \mathrm{NMR}\left(\mathrm{CDCl}_{3}, 400 \mathrm{MHz}\right): \delta=7.41$ (d, $\left.J=8.66 \mathrm{~Hz}, 2 \mathrm{H}\right), 6.64(\mathrm{~d}, J=$ $8.66 \mathrm{~Hz}, 2 \mathrm{H}), 4.15$ (s, $2 \mathrm{H}, \mathrm{NH})$.

${ }^{13} \mathrm{C}\left\{{ }^{1} \mathrm{H}\right\}$ NMR $\left(\mathrm{CDCl}_{3}, 100 \mathrm{MHz}\right): \delta=150.5,133.9,120.2,114.6,100.4$.

\section{4-Aminobenzoic Acid (2i)}

To a 5-mL sealed vial equipped with a magnetic stir bar, a solution containing 4-azidobenzoic acid $\mathbf{1 i}$ ( $98 \mathrm{mg}, 0.60 \mathrm{mmol}, 1$ equiv) in deoxygenated $\mathrm{MeOH}(4 \mathrm{~mL}), \mathrm{NiCl}_{2}(70 \mu \mathrm{L}, 42 \mathrm{mM}, 0.5 \mathrm{~mol} \%)$, and $\mathrm{NaBH}_{4}$ (56 mg, $1.5 \mathrm{mmol}, 2.5$ equiv) were added. The mixture was stirred at $\mathrm{rt}$ for $3 \mathrm{~h}$ protected from light. After completion of the reaction, the crude obtained upon solvent removal under reduced pressure, was purified via flash column chromatography (silica gel, $\mathrm{CH}_{2} \mathrm{Cl}_{2} / \mathrm{MeOH}$ 95:5) as a white precipitate (50 $\mathrm{mg}, 61 \%$ yield).

${ }^{1} \mathrm{H}$ NMR $\left(\mathrm{CD}_{3} \mathrm{OD}, 400 \mathrm{MHz}\right): \delta=7.76(\mathrm{~d}, J=7.83 \mathrm{~Hz}, 2 \mathrm{H}), 6.65(\mathrm{~d}, J=$ $7.83 \mathrm{~Hz}, 2 \mathrm{H}), 4.93$ (s, $2 \mathrm{H}, \mathrm{NH})$.

${ }^{13} \mathrm{C}\left\{{ }^{1} \mathrm{H}\right\}$ NMR $\left(\mathrm{CD}_{3} \mathrm{OD}, 100 \mathrm{MHz}\right): \delta=170.7,154.6,132.8,119.1,114.3$.

\section{4-(Benzyloxy)aniline (2j)}

The compound was obtained according to GPB using azido compound 1 j (130 mg, $0.6 \mathrm{mmol}, 1$ equiv), $\mathrm{NiCl}_{2}$ (70 $\mu \mathrm{L}, 42 \mathrm{mM}, 0.5 \mathrm{~mol} \%$ ), and $\mathrm{NaBH}_{4}$ (65 mg, $1.7 \mathrm{mmol}, 3.0$ equiv) to give the product as a yellowish precipitate (114 $\mathrm{mg}, 99 \%$ yield).

${ }^{1} \mathrm{H} \mathrm{NMR}\left(\mathrm{CDCl}_{3}, 400 \mathrm{MHz}\right): \delta=7.46-7.32$ (br, $\left.5 \mathrm{H}\right), 6.85$ (d, $J=8.65 \mathrm{~Hz}$, $2 \mathrm{H}), 6.65(\mathrm{~d}, J=8.65 \mathrm{~Hz}, 2 \mathrm{H}), 5.01(\mathrm{~s}, 2 \mathrm{H}), 3.43(\mathrm{~s}, 2 \mathrm{H}, \mathrm{NH})$.

${ }^{13} \mathrm{C}\left\{{ }^{1} \mathrm{H}\right\}$ NMR $\left(\mathrm{CDCl}_{3}, 100 \mathrm{MHz}\right): \delta=150.1,140.3,137.6,128.6,127.8$, 127.6, 116.5, 116.2, 70.9. 


\section{4-Aminophenol (2k)}

The compound was obtained according to GPB using azido compound $1 \mathbf{k}\left(80 \mathrm{mg}, 0.6 \mathrm{mmol}, 1\right.$ equiv), $\mathrm{NiCl}_{2}$ ( $70 \mu \mathrm{L}, 42 \mathrm{mM}, 0.5 \mathrm{~mol} \%$ ), and $\mathrm{NaBH}_{4}$ (38 mg, $1.5 \mathrm{mmol}, 2.5$ equiv) to give the product as a reddish precipitate ( $55 \mathrm{mg}, 85 \%$ yield).

${ }^{1} \mathrm{H}$ NMR (DMSO- $\left.d_{6}, 400 \mathrm{MHz}\right): \delta=8.36(\mathrm{~s}, 1 \mathrm{H}, \mathrm{OH}), 6.48(\mathrm{~d}, J=8.62$ $\mathrm{Hz}, 2 \mathrm{H}), 6.14$ (d, J = $8.62 \mathrm{~Hz}, 2 \mathrm{H}), 4.36(\mathrm{~s}, 2 \mathrm{H}, \mathrm{NH})$.

${ }^{13} \mathrm{C}\left\{{ }^{1} \mathrm{H}\right\}$ NMR (DMSO- $\left.d_{6}, 100 \mathrm{MHz}\right): \delta=148.2,140.6,115.5,115.2$.

\section{4-Aminobenzamide (21)}

The compound was obtained according to GPB using azido compound 11 (97 mg, $0.6 \mathrm{mmol}, 1$ equiv), $\mathrm{NiCl}_{2}$ ( $70 \mu \mathrm{L}, 42 \mathrm{mM}, 0.5 \mathrm{~mol} \%$ ), and $\mathrm{NaBH}_{4}$ (38 mg, $1.5 \mathrm{mmol}, 2.5$ equiv) to give the product as an offwhite precipitate ( $67 \mathrm{mg}, 82 \%$ yield).

${ }^{1} \mathrm{H}$ NMR $\left(\mathrm{CD}_{3} \mathrm{OD}, 400 \mathrm{MHz}\right): \delta=7.64(\mathrm{~d}, J=8.44 \mathrm{~Hz}, 2 \mathrm{H}), 6.66(\mathrm{~d}, J=$ $8.44 \mathrm{~Hz}, 2 \mathrm{H})$.

${ }^{13} \mathrm{C}\left\{{ }^{1} \mathrm{H}\right\}$ NMR $\left(\mathrm{CD}_{3} \mathrm{OD}, 100 \mathrm{MHz}\right): \delta=172.8,153.5,130.5,122.2,114.3$.

\section{4-Methoxyaniline (2m)}

The compound was obtained according to GPB using azido compound $1 \mathrm{~m}$ (75 mg, $0.5 \mathrm{mmol}, 1$ equiv), $\mathrm{NiCl}_{2}(60 \mu \mathrm{L}, 42 \mathrm{mM}, 0.5 \mathrm{~mol} \%$ ), and $\mathrm{NaBH}_{4}$ (47 mg, $1.2 \mathrm{mmol}, 2.5$ equiv) to give the product as a colorless oil (55 mg, 89\% yield).

${ }^{1} \mathrm{H} \mathrm{NMR}\left(\mathrm{CDCl}_{3}, 500 \mathrm{MHz}\right): \delta=6.75(\mathrm{~d}, J=8.79 \mathrm{~Hz}, 2 \mathrm{H}), 6.65(\mathrm{~d}, J=$ $8.79 \mathrm{~Hz}, 2 \mathrm{H}), 3.74(\mathrm{~s}, 3 \mathrm{H})$.

${ }^{13} \mathrm{C}\left\{{ }^{1} \mathrm{H}\right\}$ NMR $\left(\mathrm{CDCl}_{3}, 125 \mathrm{MHz}\right): \delta=152.8,140.0,116.6,114.9,55.8$

\section{4-Iodoaniline (2n)}

The compound was obtained according to GPB but using $\mathrm{NaBH}_{4}(0.85$ equiv) at $-20{ }^{\circ} \mathrm{C}$. Azido compound $\mathbf{1 n}(61 \mathrm{mg}, 0.25 \mathrm{mmol}, 1$ equiv), $\mathrm{NiCl}_{2}$ (30 $\mu \mathrm{L}, 42 \mathrm{mM}, 0.5 \mathrm{~mol} \%$ ), and $\mathrm{NaBH}_{4}$ (38 mg, $0.21 \mathrm{mmol}, 0.85$ equiv) afforded an off-white precipitate ( $46 \mathrm{mg}, 84 \%$ yield).

${ }^{1} \mathrm{H} \mathrm{NMR}\left(\mathrm{CDCl}_{3}, 400 \mathrm{MHz}\right): \delta=7.41(\mathrm{~d}, J=8.22 \mathrm{~Hz}, 2 \mathrm{H}), 6.46(\mathrm{~d}, J=$ $8.44 \mathrm{~Hz}, 2 \mathrm{H}), 3.64$ (br, $2 \mathrm{H}, \mathrm{NH})$.

${ }^{13} \mathrm{C}\left\{{ }^{1} \mathrm{H}\right\}$ NMR $\left(\mathrm{CDCl}_{3}, 100 \mathrm{MHz}\right): \delta=146.2,138.0,117.4,79.5$.

\section{Ethyl 2-Aminobenzoate (20)}

The compound was obtained according to GPB, employing deoxygenated EtOH as a solvent instead and using azido compound $1 \mathbf{1 0}(130 \mathrm{mg}$, $0.7 \mathrm{mmol}, 1$ equiv), $\mathrm{NiCl}_{2}$ ( $80 \mu \mathrm{L}, 42 \mathrm{mM}, 0.5 \mathrm{~mol} \%$ ), and $\mathrm{NaBH}_{4}(64$ $\mathrm{mg}, 1.7 \mathrm{mmol}, 2.5$ equiv) to give the product as a colorless oil (92 $\mathrm{mg}$, $82 \%$ yield).

$\left.{ }^{1} \mathrm{H} \mathrm{NMR} \mathrm{(CDCl}, 400 \mathrm{MHz}\right): \delta=7.79(\mathrm{~m}, 1 \mathrm{H}), 7.15(\mathrm{~m}, 1 \mathrm{H}), 6.54$ (br, 2 $\mathrm{H}, \mathrm{NH}), 4.23\left(\mathrm{q}, J=7.12 \mathrm{~Hz}, 2 \mathrm{H}, \mathrm{OCH}_{2} \mathrm{CH}_{3}\right), 1.28(\mathrm{t}, J=7.12 \mathrm{~Hz}, 3 \mathrm{H}$, $\mathrm{OCH}_{2} \mathrm{CH}_{3}$ ).

${ }^{13} \mathrm{C}\left\{{ }^{1} \mathrm{H}\right\}$ NMR $\left(\mathrm{CDCl}_{3}, 100 \mathrm{MHz}\right): \delta=168.2,152.6,134.0,131.3,116.7$, $116.3,111.1,60.3,14.4$

\section{2-Chloroaniline (2p)}

The compound was obtained according to GPB at $-20{ }^{\circ} \mathrm{C}$. Azido compound 1p (38 mg, $0.25 \mathrm{mmol}, 1$ equiv), $\mathrm{NiCl}_{2}$ (30 $\mu \mathrm{L}, 42 \mathrm{mM}, 0.5$ mol\%), and $\mathrm{NaBH}_{4}$ (23 mg, $0.61 \mathrm{mmol}, 2.5$ equiv) to give the product as a pale-yellow oil ( $25 \mathrm{mg}, 79 \%$ yield).

${ }^{1} \mathrm{H} \mathrm{NMR}\left(\mathrm{CDCl}_{3}, 400 \mathrm{MHz}\right): \delta=7.25(\mathrm{~d}, J=8.0 \mathrm{~Hz}, 1 \mathrm{H}), 7.07(\mathrm{t}, J=7.6$ $\mathrm{Hz}, 1 \mathrm{H}), 6.77$ (d, J = 8.0 Hz, $1 \mathrm{H}), 6.70(\mathrm{t}, J=7.6 \mathrm{~Hz}, 1 \mathrm{H}), 4.12(\mathrm{br}, 2 \mathrm{H}$, $\mathrm{NH})$.
${ }^{13} \mathrm{C}\left\{{ }^{1} \mathrm{H}\right\}$ NMR $\left(\mathrm{CDCl}_{3}, 100 \mathrm{MHz}\right): \delta=113.0,129.5,127.7,119.4,119.2$, 116.0 .

\section{Methyl 4-Amino-2,3,5,6-tetrafluorobenzoate (2q)}

The compound was obtained according to GPB using azido compound 1q (149 mg, $0.6 \mathrm{mmol}, 1$ equiv), $\mathrm{NiCl}_{2}$ ( $75 \mu \mathrm{L}, 42 \mathrm{mM}, 0.5 \mathrm{~mol} \%$ ), and $\mathrm{NaBH}_{4}$ (56 mg, $1.5 \mathrm{mmol}, 2.5$ equiv) to give the product as an offwhite precipitate ( $118 \mathrm{mg}, 88 \%$ yield)

${ }^{1} \mathrm{H}$ NMR $\left(\mathrm{CDCl}_{3}, 400 \mathrm{MHz}\right): \delta=4.43(\mathrm{br}, 2 \mathrm{H}, \mathrm{NH}), 3.90(\mathrm{~s}, 3 \mathrm{H}$, $\left.\mathrm{COOCH}_{3}\right)$.

${ }^{13} \mathrm{C}\left\{{ }^{1} \mathrm{H}\right\}$ NMR $\left(\mathrm{CDCl}_{3}, 100 \mathrm{MHz}\right): \delta=160.6,145.9\left(\mathrm{~d}, J_{\mathrm{C}-\mathrm{F}}=250 \mathrm{~Hz}\right)$, $135.5\left(\mathrm{~d}, J_{\mathrm{C}-\mathrm{F}}=237 \mathrm{~Hz}\right), 94.5,52.3$.

${ }^{19} \mathrm{~F} \mathrm{NMR}\left(\mathrm{CDCl}_{3}, 376 \mathrm{MHz}\right): \delta=-140.7$ (m, $\left.2 \mathrm{~F}\right),-162.3(\mathrm{~m}, 2 \mathrm{~F})$.

\section{(Azidomethyl)benzene (1a) ${ }^{47}$}

To a single-neck 100 - $\mathrm{mL}$ round-bottom flask equipped with a magnetic stir bar, containing benzyl bromide ( $1.2 \mathrm{~mL}, 10 \mathrm{mmol}, 1$ equiv) dissolved in $\mathrm{H}_{2} \mathrm{O}$ /acetone $(1: 4 ; 50 \mathrm{~mL})$, was added $\mathrm{NaN}_{3}(1.0 \mathrm{~g}, 15$ mmol, 1.5 equiv). The mixture was stirred at $\mathrm{rt}$ for $40 \mathrm{~h}$ protected from light. Acetone was removed under reduced pressure and the crude extracted with $\mathrm{CH}_{2} \mathrm{Cl}_{2}$. The organic layer was dried $\left(\mathrm{Na}_{2} \mathrm{SO}_{4}\right)$, and the pure product was obtained upon solvent removal under reduced pressure as a colorless oil ( $9.6 \mathrm{~g}, 72 \%$ yield).

${ }^{1} \mathrm{H} \mathrm{NMR}\left(\mathrm{CDCl}_{3}, 400 \mathrm{MHz}\right): \delta=7.47-7.37(\mathrm{~m}, 5 \mathrm{H}), 4.37$ (s, $\left.2 \mathrm{H}\right)$.

${ }^{13} \mathrm{C}\left\{{ }^{1} \mathrm{H}\right\}$ NMR $\left(\mathrm{CDCl}_{3}, 100 \mathrm{MHz}\right): \delta=135.5,129.0 .128 .4,128.4,54.9$.

\section{1-Azidooctane (1b)}

To a $100-\mathrm{mL}$ round-bottom flask equipped with a magnetic stir bar, $\mathrm{CHCl}_{3}(40 \mathrm{~mL})$ and octan-1-ol ( $40 \mu \mathrm{L}, 1.0 \mathrm{mmol}, 1$ equiv) were added. The mixture was then cooled to $5^{\circ} \mathrm{C}$ and pyridine $(160 \mu \mathrm{L}, 0.75 \mathrm{mmol}$, 3 equiv), together with $p$-toluenesulfonyl chloride $(380 \mathrm{mg}, 2.0 \mathrm{mmol}$, 2 equiv), added in small portions, were introduced. The reaction was stirred for $3 \mathrm{~h}$ until all the starting material was consumed as monitored by TLC analysis. The solvent was removed under reduced pressure and the crude dissolved in $\mathrm{Et}_{2} \mathrm{O}$ and washed with $2 \mathrm{M}$ aq $\mathrm{HCl}$, concd aq $\mathrm{NaHCO}_{3}$, and $\mathrm{H}_{2} \mathrm{O}$. The ethereal phase was dried $\left(\mathrm{Na}_{2} \mathrm{SO}_{4}\right)$ and concentrated in vacuo. The crude was dissolved in $\mathrm{H}_{2} \mathrm{O}$ /acetone $(1: 5 ; 20 \mathrm{~mL})$ in a $50-\mathrm{mL}$ round-bottom flask equipped with magnetic stir bar and a condenser. To the mixture was added $\mathrm{NaN}_{3}(440 \mathrm{mg}, 2.4$ mmol, 2.5 equiv) and then it was stirred at reflux for $24 \mathrm{~h}$. Acetone was removed under reduced pressure and the crude extracted with $\mathrm{Et}_{2} \mathrm{O}$. The organic layer was dried $\left(\mathrm{Na}_{2} \mathrm{SO}_{4}\right)$, and the crude obtained upon solvent removal in vacuo was purified via flash column chromatography (silica gel, petroleum ether/ $\mathrm{Et}_{2} \mathrm{O} 98: 2, R_{f}=0.15$ ) to afford the pure product as a colorless oil ( $57 \mathrm{mg}, 37 \%$ yield).

${ }^{1} \mathrm{H} \mathrm{NMR}\left(\mathrm{CDCl}_{3}, 400 \mathrm{MHz}\right): \delta=3.25\left(\mathrm{t}, J=6.96 \mathrm{~Hz}, 2 \mathrm{H}, \mathrm{CH}_{2} \mathrm{~N}_{3}\right), 1.60$ $(\mathrm{m}, 2 \mathrm{H}), 1.36-1.28(\mathrm{~m}, 10 \mathrm{H}), 0.88\left(\mathrm{t}, J=6.72 \mathrm{~Hz}, 3 \mathrm{H}, \mathrm{CH}_{2} \mathrm{CH}_{3}\right)$.

${ }^{13} \mathrm{C}\left\{{ }^{1} \mathrm{H}\right\}$ NMR $\left(\mathrm{CDCl}_{3}, 100 \mathrm{MHz}\right): \delta=51.7,31.9,29.3,29.3,29.0,26.9$, $22.8,14.2$.

\section{2-[2-(2-Azidoethoxy)ethoxy]ethan-1-ol (1c) ${ }^{48}$}

To a 25-mL round-bottom flask equipped with a magnetic stir bar, containing 2-[2-(2-chloroethoxy)ethoxy]ethanol ( $1.0 \mathrm{~mL}, 6.9 \mathrm{mmol}, 1$ equiv) dissolved in $\mathrm{H}_{2} \mathrm{O}(10 \mathrm{~mL})$, were added $\mathrm{NaI}(207 \mathrm{mg}, 1.4 \mathrm{mmol}$, 0.2 equiv) and $\mathrm{NaN}_{3}$ ( $4.4 \mathrm{~g}, 68 \mathrm{mmol}, 10$ equiv). The mixture was stirred for $56 \mathrm{~h}$ at $50{ }^{\circ} \mathrm{C}$ protected from light. The product was extracted with EtOAc $(4 \times 20 \mathrm{~mL})$ and washed with sat. aq $\mathrm{NaCl}$. The or- 
ganic layer was dried $\left(\mathrm{Na}_{2} \mathrm{SO}_{4}\right)$, and the pure product was obtained upon solvent removal under reduced pressure as a pale yellow oil ( $1.039 \mathrm{~g}, 86 \%$ yield).

${ }^{1} \mathrm{H} \mathrm{NMR}\left(\mathrm{CDCl}_{3}, 400 \mathrm{MHz}\right): \delta=3.74(\mathrm{~m}, 2 \mathrm{H}), 3.69(\mathrm{~m}, 6 \mathrm{H}), 3.62(\mathrm{~m}, 2$ $\mathrm{H}), 3.40(\mathrm{t}, J=4.87 \mathrm{~Hz}, 2 \mathrm{H}), 1.80(\mathrm{br}, 1 \mathrm{H})$.

${ }^{13} \mathrm{C}\left\{{ }^{1} \mathrm{H}\right\} \mathrm{NMR}\left(\mathrm{CDCl}_{3}, 100 \mathrm{MHz}\right): \delta=72.6,70.8,70.6,70.2,62.0,50.8$.

\section{Azidocyclohexane (1d) $)^{49}$}

To a $250-\mathrm{mL}$ round-bottom flask equipped with a magnetic stir bar, flame dried, were introduced under inert atmosphere, bromocyclohexene (1.25 mL, $10.2 \mathrm{mmol}, 1$ equiv) dissolved in anhyd DMF (60 $\mathrm{mL}$ ) and $\mathrm{NaN}_{3}(1.5 \mathrm{~g}, 22 \mathrm{mmol}, 2.2$ equiv). The reaction was stirred for $17 \mathrm{~h}$ at $80^{\circ} \mathrm{C}$ protected from light. The product was extracted with $\mathrm{Et}_{2} \mathrm{O}(4 \times 50 \mathrm{~mL})$ and washed with brine $(6 \times 30 \mathrm{~mL})$. The organic layer was dried $\left(\mathrm{Na}_{2} \mathrm{SO}_{4}\right)$, and the pure product was obtained upon solvent removal under reduced pressure as a colorless oil ( $0.766 \mathrm{~g}, 60 \%$ yield). ${ }^{1} \mathrm{H} \mathrm{NMR}\left(\mathrm{CDCl}_{3}, 400 \mathrm{MHz}\right): \delta=3.36-3.31(\mathrm{~m}, 1 \mathrm{H}), 1.91-1.75(\mathrm{~m}, 2 \mathrm{H})$, $1.59-1.54(\mathrm{~m}, 1 \mathrm{H}), 1.39-1.22(\mathrm{~m}, 5 \mathrm{H})$.

${ }^{13} \mathrm{C}\left\{{ }^{1} \mathrm{H}\right\} \operatorname{NMR}\left(\mathrm{CDCl}_{3}, 100 \mathrm{MHz}\right): \delta=60.1,31.8,25.4,24.4$.

\section{1-Azidoadamantane (1e) $)^{50}$}

To a $5 \mathrm{~mL}$ sealed vial equipped with a magnetic stir bar, were introduced, $\mathrm{MeNO}_{2}$ (1.4 mL), adamantan-1-ol ( $425 \mathrm{mg}, 2.8 \mathrm{mmol}, 1$ equiv), trimethylsilyl azide ( $1.1 \mathrm{~mL}, 8.4 \mathrm{mmol}, 3.0$ equiv), and triflic acid (55 $\mu \mathrm{L}, 0.6 \mathrm{mmol}, 0.22$ equiv). The reaction was stirred at $30{ }^{\circ} \mathrm{C}$ for $3 \mathrm{~h}$ until all the starting material resulted consumed according to TLC analysis. Volatiles were removed via rotary evaporation and the pure product was obtained after flash column chromatography (silica gel, petroleum ether, $R_{f}=0.45$ ) as a white precipitate ( $342 \mathrm{mg}$, 69\% yield). ${ }^{1} \mathrm{H} \mathrm{NMR}\left(\mathrm{CDCl}_{3}, 400 \mathrm{MHz}\right): \delta=2.15(\mathrm{~s}, 3 \mathrm{H}), 1.80(\mathrm{~d}, J=2.43 \mathrm{~Hz}, 6 \mathrm{H})$, $1.62-1.71(\mathrm{~m}, 6 \mathrm{H})$.

${ }^{13} \mathrm{C}\left\{{ }^{1} \mathrm{H}\right\} \operatorname{NMR}\left(\mathrm{CDCl}_{3}, 100 \mathrm{MHz}\right): \delta=59.05,41.62,36.01,29.92$.

\section{Methyl 6-0-Tosyl-a-D-glucopyranoside ${ }^{51}$}

To a two-necked 100 -mL round-bottom flask equipped with a magnetic stir bar, flame dried, were introduced under inert atmosphere, methyl $\alpha$-D-glucopyranoside ( $1.56 \mathrm{~g}, 8.0 \mathrm{mmol}, 1$ equiv) dissolved in dry pyridine $(40 \mathrm{~mL})$, and p-toluenesulfonyl chloride $(1.9 \mathrm{~g}, 10.0$ mmol, 1.2 equiv). The mixture was cooled to $-20^{\circ} \mathrm{C}$ and stirred overnight under inert atmosphere. At the end of the reaction, pyridine was removed as an azeotrope of toluene via rotary evaporation, the pure product was obtained after flash column chromatography (silica gel, gradient: $0 \%$ to $10 \% \mathrm{MeOH}$ in EtOAc) as white precipitate (1.533 g, $55 \%$ yield).

${ }^{1} \mathrm{H}$ NMR (DMSO- $\left.d_{6}, 500 \mathrm{MHz}\right): \delta=7.77(\mathrm{~d}, J=8.3 \mathrm{~Hz}, 2 \mathrm{H}, \mathrm{Ar}$ ), 7.48 (d, $J=8.0 \mathrm{~Hz}, 2 \mathrm{H}, \mathrm{Ar}), 5.16(\mathrm{~d}, J=5.9 \mathrm{~Hz}, 1 \mathrm{H}, \mathrm{OH}), 4.89(\mathrm{~d}, J=5.1 \mathrm{~Hz}, 1 \mathrm{H}$, OH). 4.80 (d, J= $6.4 \mathrm{~Hz}, 1 \mathrm{H}, \mathrm{OH}), 4.48$ (d, J= 3.6 Hz, $1 \mathrm{H}, \mathrm{H}-1), 4.21$ (dd, $J=10.6,1.8 \mathrm{~Hz}, 1 \mathrm{H}, \mathrm{H}-6), 4.05(\mathrm{dd}, J=10.6,6.4 \mathrm{~Hz}, 1 \mathrm{H}, \mathrm{H}-6), 3.49(\mathrm{~m}$, $1 \mathrm{H}), 3.20\left(\mathrm{~s}, 3 \mathrm{H}, \mathrm{OCH}_{3}\right), 3.14(\mathrm{~m}, 1 \mathrm{H}), 2.99(\mathrm{~m}, 1 \mathrm{H}), 2.42(\mathrm{~s}, 3 \mathrm{H}$, Ts$\left.\mathrm{CH}_{3}\right)$.

${ }^{13} \mathrm{C}\left\{{ }^{1} \mathrm{H}\right\}$ NMR (DMSO- $d_{6}, 125 \mathrm{MHz}$ ): $\delta=144.9,132.4,130.1,127.6$, 99.7, 73.0, 71.6, 70.3, 69.8, 69.4, 54.5, 21.1 .

\section{Methyl 6-0-Tosyl-2,3,4-tri-0-benzyl- $\alpha$-D-glucopyranoside ${ }^{52}$}

To a two-necked $50-\mathrm{mL}$ round-bottom flask equipped with a magnetic stir bar, flame dried, was introduced methyl 6-O-tosyl- $\alpha$-D-glucopyranoside (416 mg, $1.2 \mathrm{mmol}, 1$ equiv) dissolved in dry DMF (20 mL). The mixture was cooled down to $0{ }^{\circ} \mathrm{C}$ in an ice bath and, under inert atmosphere, were added benzyl bromide $(1.0 \mathrm{~mL}, 8.2 \mathrm{mmol}, 6.9$ equiv) and $\mathrm{NaH}$ (60\% dispersion in mineral oil) $(238 \mathrm{mg}, 6.0 \mathrm{mmol}, 5.0$ equiv). The reaction was stirred under inert atmosphere at $0{ }^{\circ} \mathrm{C}$ for $1 \mathrm{~h}$ then it was allowed to reach rt overnight. The reaction was quenched with $\mathrm{H}_{2} \mathrm{O}(25 \mathrm{~mL})$ and extracted with $\mathrm{Et}_{2} \mathrm{O}(4 \times 20 \mathrm{~mL})$. The ethereal layer was dried $\left(\mathrm{Na}_{2} \mathrm{SO}_{4}\right)$. The pure product was obtained after flash column chromatography (silica gel, petroleum ether/EtOAc 4:1) as white crystalline precipitate $(238 \mathrm{mg}, 32 \%$ yield).

${ }^{1} \mathrm{H} \mathrm{NMR}\left(\mathrm{CDCl}_{3}, 400 \mathrm{MHz}\right): \delta=7.76-7.78(\mathrm{~m}, 2 \mathrm{H}, \mathrm{Ar}), 7.26-7.40(\mathrm{~m}$, $15 \mathrm{H}, \mathrm{Ar}$ ), 7.15-7.17 (m, $2 \mathrm{H}, \mathrm{Ar}), 4.98$ (d, $J=10.9 \mathrm{~Hz}, 1 \mathrm{H}, \mathrm{CH}_{2} \mathrm{Ph}$ ), 4.76-4.85 (m, $\left.3 \mathrm{H}, \mathrm{CH}_{2} \mathrm{Ph}\right), 4.64\left(\mathrm{~d}, J=12.1 \mathrm{~Hz}, 1 \mathrm{H}, \mathrm{CH}_{2} \mathrm{Ph}\right.$ ), 4.53 (d, $J=$ $3.4 \mathrm{~Hz}, 1 \mathrm{H}, \mathrm{H}-1), 4.44$ (d, J = $\left.10.7 \mathrm{~Hz}, 1 \mathrm{H}, \mathrm{CH}_{2} \mathrm{Ph}\right), 4.19-4.21(\mathrm{~m}, 2 \mathrm{H})$, $3.96(\mathrm{t}, J=9.23 \mathrm{~Hz}, 1 \mathrm{H}), 3.77(\mathrm{~m}, 1 \mathrm{H}), 3.43-3.50(\mathrm{~m}, 2 \mathrm{H}), 3.32(\mathrm{~s}, 3 \mathrm{H}$, $\left.\mathrm{OCH}_{3}\right), 2.39\left(\mathrm{~s}, 3 \mathrm{H}, \mathrm{Ts}-\mathrm{CH}_{3}\right)$.

${ }^{13} \mathrm{C}\left\{{ }^{1} \mathrm{H}\right\}$ NMR $\left(\mathrm{CDCl}_{3}, 100 \mathrm{MHz}\right): \delta=144.9,138.7,138.1,137.9,133.0$, $129.9,128.6,128.51,128.50,128.2,128.1,128.0,127.98,127.94$, $127.8,98.1,81.9,79.8,77.0,75.8,75.1,73.5,68.7,68.6,55.4,21.7$.

\section{Methyl 6-Azido-2,3,4-tri-0-benzyl-6-deoxy-a-D-glucopyranoside (1f) $)^{53}$}

To a 25-mL round-bottom flask equipped with a magnetic stir bar, flame dried, were introduced under inert atmosphere, $\mathrm{NaN}_{3}(81 \mathrm{mg}$, $1.2 \mathrm{mmol}, 3.3$ equiv) and methyl 6-O-tosyl-2,3,4-tri-O-benzyl- $\alpha$-Dglucopyranoside (234 mg, $0.38 \mathrm{mmol}, 1$ equiv) dissolved in anhyd DMF $(10 \mathrm{~mL})$. The reaction was stirred for $4 \mathrm{~h}$ at $85^{\circ} \mathrm{C}$ under inert atmosphere protected from light. The product was extracted from $\mathrm{H}_{2} \mathrm{O}$ $(15 \mathrm{~mL})$ with $\mathrm{Et}_{2} \mathrm{O}(4 \times 15 \mathrm{~mL})$ and washed with brine $(5 \times 20 \mathrm{~mL})$. The organic layer was dried $\left(\mathrm{Na}_{2} \mathrm{SO}_{4}\right)$, and the pure product was obtained after flash column chromatography (silica gel petroleum ether $/ \mathrm{CH}_{2} \mathrm{Cl}_{2} /$ EtOAc 10:1:1 $\rightarrow$ 6:1:1, $R_{f}=0.38$ ) as a colorless oil $(143 \mathrm{mg}$, $77 \%$ yield).

${ }^{1} \mathrm{H} \mathrm{NMR}\left(\mathrm{CDCl}_{3}, 500 \mathrm{MHz}\right): \delta=7.25-7.37(\mathrm{~m}, 15 \mathrm{H}, \mathrm{Ar}), 5.00(\mathrm{~d}, J=$ $\left.10.9 \mathrm{~Hz}, 1 \mathrm{H}, \mathrm{CH}_{2} \mathrm{Ph}\right), 4.90$ (d, $\left.J=11.1 \mathrm{~Hz}, 1 \mathrm{H}, \mathrm{CH}_{2} \mathrm{Ph}\right), 4.80(\mathrm{~m}, 2 \mathrm{H}$, $\left.\mathrm{CH}_{2} \mathrm{Ph}\right), 4.67\left(\mathrm{~d}, J=12.1 \mathrm{~Hz}, 1 \mathrm{H}, \mathrm{CH}_{2} \mathrm{Ph}\right), 4.62(\mathrm{~d}, J=3.6 \mathrm{~Hz}, 1 \mathrm{H}, \mathrm{H}-1)$, $4.58\left(\mathrm{~d}, J=11.1 \mathrm{~Hz}, 1 \mathrm{H}, \mathrm{CH}_{2} \mathrm{Ph}\right), 3.99(\mathrm{t}, J=9.3 \mathrm{~Hz}, 1 \mathrm{H}), 3.78(\mathrm{~m}, 1 \mathrm{H})$, $3.54(\mathrm{dd}, J=9.6,3.6 \mathrm{~Hz}, 1 \mathrm{H}), 3.44(\mathrm{~m}, 2 \mathrm{H}), 3.40\left(\mathrm{~s}, 3 \mathrm{H}, \mathrm{OCH}_{3}\right), 3.33$ (dd, $J=13.0,5.7 \mathrm{~Hz}, 1 \mathrm{H}$ ).

${ }^{13} \mathrm{C}\left\{{ }^{1} \mathrm{H}\right\} \mathrm{NMR}\left(\mathrm{CDCl}_{3}, 125 \mathrm{MHz}\right): \delta=138.7,138.1,138.0,128.6,128.59$, 128.53, 128.19, 128.09, 128.07, 128.06, 128.03, 127.8, 98.1, 81.9, 80.1, 78.4, 75.9, 75.2, 73.5, 70.0, 55.5, 51.5.

\section{Azidobenzene (1g)}

The compound was obtained according GPC using boronic acid (536 $\mathrm{mg}, 4.3 \mathrm{mmol}, 1$ equiv), $\mathrm{NaN}_{3}$ ( $410 \mathrm{mg}, 6.3 \mathrm{mmol}, 1.5$ equiv), and $\mathrm{Cu}(\mathrm{OAc})_{2}(40 \mathrm{mg}, 0.22 \mathrm{mmol}, 0.05$ equiv). After $24 \mathrm{~h}$ of reaction the crude was worked up and the pure product was obtained after flash column chromatography (silica gel, petroleum ether/ $\mathrm{Et}_{2} \mathrm{O} 98: 2, R_{f}=$ 0.85 ) as a colorless oil (297 $\mathrm{mg}, 58 \%$ yield).

${ }^{1} \mathrm{H} \mathrm{NMR}\left(\mathrm{CDCl}_{3}, 400 \mathrm{MHz}\right): \delta=7.36(\mathrm{t}, J=7.6 \mathrm{~Hz}, 2 \mathrm{H}), 7.15(\mathrm{t}, J=7.6$ $\mathrm{Hz}, 1 \mathrm{H}), 7.04$ (d, J = 8.4 Hz, $2 \mathrm{H}$ ).

${ }^{13} \mathrm{C}\left\{{ }^{1} \mathrm{H}\right\} \operatorname{NMR}\left(\mathrm{CDCl}_{3}, 100 \mathrm{MHz}\right): \delta=140.2,129.9,125.0,119.2$.

\section{4-Azidobenzonitrile (1h)}

The compound was obtained according GPC using boronic acid (146 $\mathrm{mg}, 1.0 \mathrm{mmol}, 1$ equiv), $\mathrm{NaN}_{3}$ (100 mg, $1.5 \mathrm{mmol}, 1.5$ equiv), and $\mathrm{Cu}(\mathrm{OAc})_{2}(18 \mathrm{mg}, 0.1 \mathrm{mmol}, 0.1$ equiv). After $19 \mathrm{~h}$ of reaction the crude was worked up and the pure product was obtained after flash column chromatography (silica gel, petroleum ether/ $\mathrm{Et}_{2} \mathrm{O}$ 90:10) as a white crystalline precipitate ( $92 \mathrm{mg}, 64 \%$ yield). 
${ }^{1} \mathrm{H} \mathrm{NMR}\left(\mathrm{CDCl}_{3}, 400 \mathrm{MHz}\right): \delta=7.63(\mathrm{~d}, J=8.0 \mathrm{~Hz}, 2 \mathrm{H}), 7.09(\mathrm{~d}, J=8.0$ $\mathrm{Hz}, 2 \mathrm{H})$.

${ }^{13} \mathrm{C}\left\{{ }^{1} \mathrm{H}\right\} \operatorname{NMR}\left(\mathrm{CDCl}_{3}, 100 \mathrm{MHz}\right): \delta=144.9,133.8,119.7,118.4,108.3$.

\section{4-Azidobenzoic Acid (1i)}

The compound was obtained according GPC using boronic acid (500 $\mathrm{mg}, 3.0 \mathrm{mmol}, 1$ equiv), $\mathrm{NaN}_{3}$ ( $250 \mathrm{mg}, 3.8 \mathrm{mmol}, 1.3$ equiv), and $\mathrm{Cu}(\mathrm{OAc})_{2}(50 \mathrm{mg}, 0.3 \mathrm{mmol}, 0.1$ equiv). After $24 \mathrm{~h}$ of reaction the crude was dissolved in $1 \mathrm{M}$ aq $\mathrm{HCl}$ and the product extracted with EtOAc, washed with brine, and the organic layer dried $\left(\mathrm{Na}_{2} \mathrm{SO}_{4}\right)$. The compound was purified by recrystallization (EtOAc) as off-white crystals ( $210 \mathrm{mg}, 43 \%$ yield).

${ }^{1} \mathrm{H}$ NMR (DMSO- $d_{6}, 400 \mathrm{MHz}$ ): $\delta=12.97(\mathrm{br}, 1 \mathrm{H}, \mathrm{COOH}), 7.96(\mathrm{~d}, J=$ $8.6 \mathrm{~Hz}, 2 \mathrm{H}), 7.22(\mathrm{~d}, J=8.6 \mathrm{~Hz}, 2 \mathrm{H})$.

${ }^{13} \mathrm{C}\left\{{ }^{1} \mathrm{H}\right\}$ NMR (DMSO- $\left.d_{6}, 100 \mathrm{MHz}\right): \delta=166.6,143.9,131.2,127.3$, 119.2.

\section{1-Azido-4-(benzyloxy)benzene ( $1 \mathbf{j})$}

The compound was obtained according GPC using boronic acid (670 $\mathrm{mg}, 3.0 \mathrm{mmol}, 1$ equiv), $\mathrm{NaN}_{3}$ (265 mg, $4.1 \mathrm{mmol}, 1.4$ equiv), and $\mathrm{Cu}(\mathrm{OAc})_{2}(53 \mathrm{mg}, 0.3 \mathrm{mmol}, 0.1$ equiv). After $24 \mathrm{~h}$ of reaction the crude was worked up and the pure product was obtained after flash column chromatography (silica gel, petroleum ether $/ \mathrm{Et}_{2} \mathrm{O}$ 98:2, $R_{f}=$ 0.17 ) as an off-white precipitate (608 $\mathrm{mg}, 90 \%$ yield).

${ }^{1} \mathrm{H}$ NMR $\left(\mathrm{CDCl}_{3}, 400 \mathrm{MHz}\right): \delta=7.43-7.33(\mathrm{~m}, 5 \mathrm{H}), 6.96(\mathrm{~s}, 4 \mathrm{H}), 5.05$ $(\mathrm{s}, 2 \mathrm{H})$.

${ }^{13} \mathrm{C}\left\{{ }^{1} \mathrm{H}\right\}$ NMR $\left(\mathrm{CDCl}_{3}, 100 \mathrm{MHz}\right): \delta=156.3,136.9,132.8,128.8,128.2$, $127.6,120.2,116.3,70.6$.

\section{4-Azidophenol (1k) $)^{54}$}

To a $100-\mathrm{mL}$ round-bottom flask equipped with a magnetic stir bar, 4-aminophenol (1.24 g, $11.4 \mathrm{mmol}, 1$ equiv) was dissolved in $2 \mathrm{M}$ aq $\mathrm{HCl}(35 \mathrm{~mL})$. The solution was cooled down to $0{ }^{\circ} \mathrm{C}$ and $\mathrm{NaNO}_{2}(1.7 \mathrm{~g}$, $24.2 \mathrm{mmol}, 2$ equiv) was added in portions and the mixture was stirred for $30 \mathrm{~min}$. $\mathrm{NaN}_{3}(1.1 \mathrm{~g}, 17.0 \mathrm{mmol}, 1.5$ equiv) was added stepwise to the mixture (development of $\mathrm{N}_{2}$ observed) and upon addition, the reaction was further stirred at $0{ }^{\circ} \mathrm{C}$ for 30 min protected from light. The aqueous solution was neutralized with sat. aq $\mathrm{NaHCO}_{3}$ and extracted with $\mathrm{Et}_{2} \mathrm{O}(6 \times 30 \mathrm{~mL})$. The organic layer was dried $\left(\mathrm{Na}_{2} \mathrm{SO}_{4}\right)$, and solvent removed under reduced pressure. The crude was purified by flash column chromatography (petroleum ether/EtOAc 10:1) affording the product as a white precipitate ( $462 \mathrm{mg}, 30 \%$ yield).

${ }^{1} \mathrm{H} \mathrm{NMR}\left(\mathrm{CDCl}_{3}, 400 \mathrm{MHz}\right): \delta=6.93(\mathrm{~d}, J=8.8 \mathrm{~Hz}, 2 \mathrm{H}), 6.85$ (d, $J=8.8$ $\mathrm{Hz}, 2 \mathrm{H}), 4.81$ (br, $1 \mathrm{H}, \mathrm{OH})$

${ }^{13} \mathrm{C}\left\{{ }^{1} \mathrm{H}\right\} \operatorname{NMR}\left(\mathrm{CDCl}_{3}, 100 \mathrm{MHz}\right): \delta=153.1,132.6,120.3,116.8$.

\section{4-Azidobenzamide (11)}

The compound was obtained according GPC using boronic acid (412 $\mathrm{mg}, 2.5 \mathrm{mmol}, 1$ equiv), $\mathrm{NaN}_{3}$ ( $243 \mathrm{mg}, 3.7 \mathrm{mmol}, 1.5$ equiv), and $\mathrm{Cu}(\mathrm{OAc})_{2}$ (45 mg, $0.25 \mathrm{mmol}, 0.1$ equiv). After $24 \mathrm{~h}$ of reaction, the crude was worked up without further purification, affording a white precipitate (296 $\mathrm{mg}, 73 \%$ yield).

${ }^{1} \mathrm{H}$ NMR $\left(\mathrm{CD}_{3} \mathrm{OD}, 400 \mathrm{MHz}\right): \delta=7.91(\mathrm{~d}, J=8.6 \mathrm{~Hz}, 2 \mathrm{H}), 7.15(\mathrm{~d}, J=8.5$ $\mathrm{Hz}, 2 \mathrm{H})$.

${ }^{13} \mathrm{C}\left\{{ }^{1} \mathrm{H}\right\}$ NMR $\left(\mathrm{CD}_{3} \mathrm{OD}, 100 \mathrm{MHz}\right): \delta=171.3,145.2,131.5,130.6,119.9$.

\section{1-Azido-4-methoxybenzene (1 $\mathrm{m})$}

The compound was obtained according GPC using boronic acid (300 $\mathrm{mg}, 2.0 \mathrm{mmol}, 1$ equiv), $\mathrm{NaN}_{3}$ (190 mg, $3.0 \mathrm{mmol}, 1.5$ equiv), and $\mathrm{Cu}(\mathrm{OAc})_{2}(36 \mathrm{mg}, 0.2 \mathrm{mmol}, 0.1$ equiv). After $24 \mathrm{~h}$ of reaction, the crude was worked up without further purification, affording a paleyellow oil (215 mg, 72\% yield).

${ }^{1} \mathrm{H}$ NMR $\left(\mathrm{CD}_{3} \mathrm{OD}, 400 \mathrm{MHz}\right): \delta=6.99-6.93(\mathrm{~m}, 4 \mathrm{H}), 3.78(\mathrm{~s}, 3 \mathrm{H}$, $\mathrm{OCH}_{3}$.

${ }^{13} \mathrm{C}\left\{{ }^{1} \mathrm{H}\right\}$ NMR $\left(\mathrm{CD}_{3} \mathrm{OD}, 100 \mathrm{MHz}\right): \delta=158.7,133.6,121.0,116.3,56.0$.

\section{Ethyl 2-Azidobenzoate (10)}

The compound was obtained according GPC, employing EtOH as the solvent, using boronic acid ( $380 \mathrm{mg}, 2.0 \mathrm{mmol}, 1$ equiv), $\mathrm{NaN}_{3}(190$ $\mathrm{mg}, 3.0 \mathrm{mmol}, 1.5$ equiv), and $\mathrm{Cu}(\mathrm{OAc})_{2}$ ( $36 \mathrm{mg}, 0.2 \mathrm{mmol}, 0.1$ equiv). After $24 \mathrm{~h}$ of reaction, the crude was worked up and the pure product was obtained after flash column chromatography (silica gel, petroleum ether/EtOAc 20:1) as a colorless oil (134 mg, 35\% yield).

${ }^{1} \mathrm{H} \mathrm{NMR}\left(\mathrm{CDCl}_{3}, 400 \mathrm{MHz}\right): \delta=7.85(\mathrm{~d}, J=7.8 \mathrm{~Hz}, 1 \mathrm{H}), 7.50(\mathrm{~m}, 1 \mathrm{H})$, 7.23-7.15 (m, $2 \mathrm{H}), 4.37\left(\mathrm{q}, J=7.1 \mathrm{~Hz}, 2 \mathrm{H}, \mathrm{OCH}_{2} \mathrm{CH}_{3}\right), 1.39$ (t, $J=7.1$ $\left.\mathrm{Hz}, 3 \mathrm{H}, \mathrm{OCH}_{2} \mathrm{CH}_{3}\right)$.

${ }^{13} \mathrm{C}\left\{{ }^{1} \mathrm{H}\right\}$ NMR $\left(\mathrm{CDCl}_{3}, 100 \mathrm{MHz}\right): \delta=165.2,139.9,133.0,131.64,124.4$, $123.0,119.8,61.3,14.2$

\section{Methyl 4-Azido-2,3,5,6-tetrafluorobenzoate (1q) ${ }^{55}$}

Methyl pentafluorobenzoate $(9.5 \mathrm{~g}, 40 \mathrm{mmol})$ was dissolved in acetone $/ \mathrm{H}_{2} \mathrm{O}(2: 1 ; 90 \mathrm{~mL}) . \mathrm{NaN}_{3}(3.40 \mathrm{~g}, 52 \mathrm{mmol}, 1.3$ equiv) was added to the flask and the mixture was refluxed at $85{ }^{\circ} \mathrm{C}$ for $6 \mathrm{~h}$. The mixture was subsequently cooled to rt, diluted with water $(150 \mathrm{~mL})$, and extracted with $\mathrm{Et}_{2} \mathrm{O}(3 \times 150 \mathrm{~mL})$. The combined organic extracts were dried $\left(\mathrm{MgSO}_{4}\right)$ and the solvent removed under reduced pressure. The product was obtained after flash column chromatography (silica gel, hexane/EtOAc 40:1) as white crystals ( $9.467 \mathrm{~g}, 95 \%$ yield).

${ }^{1} \mathrm{H} \mathrm{NMR}\left(\mathrm{CDCl}_{3}, 400 \mathrm{MHz}\right): \delta=3.97\left(\mathrm{~s}, 3 \mathrm{H}, \mathrm{OCH}_{3}\right)$.

${ }^{13} \mathrm{C}\left\{{ }^{1} \mathrm{H}\right\}$ NMR $\left(\mathrm{CDCl}_{3}, 100 \mathrm{MHz}\right): \delta=160.0,145.5\left(\mathrm{dm}, J_{\mathrm{C}-\mathrm{F}}=252 \mathrm{~Hz}\right)$, $140.6\left(\mathrm{dm}, J_{\mathrm{C}-\mathrm{F}}=250 \mathrm{~Hz}\right), 123.5,107.8,53.4$.

${ }^{19} \mathrm{~F} \mathrm{NMR}\left(\mathrm{CDCl}_{3}, 376 \mathrm{MHz}\right): \delta=-158.6(\mathrm{~m}, 2 \mathrm{~F}),-150.9(\mathrm{~m}, 2 \mathrm{~F})$.

\section{Conflict of Interest}

The authors declare no conflict of interest.

\section{Funding Information}

K.J.P., G.P. and P.D. thank the Wenner-Gren Stiftelserna (Grant No. UPD2016-0084) and KTH Royal institute of Technology for financial support.

\section{Acknowledgment}

The authors would like to thank Yi Yang and Prof. Mat Jonsson for the help with ICP-OES analyses.

\section{Supporting Information}

Supporting information for this article is available online at https://doi.org/10.1055/a-1579-2190. 


\section{References}

(1) Downing, R.; Kunkeler, P.; Van Bekkum, H. Catal. Today 1997, $37,121$.

(2) (a) Ono, N. The Nitro Group in Organic Synthesis; John Wiley \& Sons: New York, 2001. (b) Nishimura, S. Handbook of Heterogeneous Catalytic Hydrogenation for Organic Synthesis; John Wiley \& Sons: New York, 2001.

(3) (a) Aditya, T.; Pal, A.; Pal, T. Chem. Commun. 2015, 51, 9410. (b) Campelo, J. M.; Luna, D.; Luque, R.; Marinas, J. M.; Romero, A. A. ChemSusChem 2009, 2, 18.

(4) (a) Boronat, M.; Concepción, P.; Corma, A.; González, S.; Illas, F.; Serna, P. J. Am. Chem. Soc. 2007, 129, 16230. (b) Adhikari, B.; Biswas, A.; Banerjee, A. ACS Appl. Mater. Interfaces 2012, 4, 5472.

(5) Takasaki, M.; Motoyama, Y.; Higashi, K.; Yoon, S.-H.; Mochida, I.; Nagashima, H. Org. Lett. 2008, 10, 1601.

(6) Nie, R.; Wang, J.; Wang, L.; Qin, Y.; Chen, P.; Hou, Z. Carbon 2012, 50, 586

(7) (a) Tuteja, J.; Nishimura, S.; Ebitani, K. RSC Adv. 2014, 4, 38241. (b) Wang, P.; Liu, H.; Niu, J.; Li, R.; Ma, J. Catal. Sci. Technol. 2014, 4, 1333. (c) Yamada, Y. M.; Yuyama, Y.; Sato, T.; Fujikawa, S.; Uozumi, Y. Angew. Chem. Int. Ed. 2014, 53, 127. (d) Guo, Y.; Li, J.; Zhao, F.; Lan, G.; Li, L.; Liu, Y.; Si, Y.; Jiang, Y.; Yang, B.; Yang, R. RSC Adv. 2016, 6, 7950 .

(8) Zhao, Z.; Yang, H.; Li, Y.; Guo, X. Green Chem. 2014, 16, 1274.

(9) (a) Rathore, P. S.; Patidar, R.; Shripathi, T.; Thakore, S. Catal. Sci. Technol. 2015, 5, 286. (b) Kalbasi, R. J.; Zamani, F. RSC Adv. 2014, 4, 7444. (c) Zamani, F.; Kianpour, S. Catal. Commun. 2014, 45, 1. (d) Ren, Y.; Wei, H.; Yin, G.; Zhang, L.; Wang, A.; Zhang, T. Chem. Commun. 2017, 53, 1969.

(10) (a) Gao, G.; Tao, Y.; Jiang, J. Green Chem. 2008, 10, 439. (b) Dey, R.; Mukherjee, N.; Ahammed, S.; Ranu, B. C. Chem. Commun. 2012, 48, 7982. (c) Moghaddam, M. M.; Pieber, B.; Glasnov, T.; Kappe, C. O. ChemSusChem 2014, 7, 3122. (d) MacNair, A. J.; Tran, M.-M.; Nelson, J. E.; Sloan, G. U.; Ironmonger, A.; Thomas, S. P. Org. Biomol. Chem. 2014, 12, 5082. (e) Gu, X.; Sun, Z.; Wu, S.; Qi, W.; Wang, H.; Xu, X.; Su, D. Chem. Commun. 2013, 49, 10088. (f) Jagadeesh, R. V.; Surkus, A.-E.; Junge, H.; Pohl, M.-M.; Radnik, J.; Rabeah, J.; Huan, H.; Schünemann, V.; Brückner, A.; Beller, M. Science 2013, 342, 1073. (g) Jagadeesh, R. V.; Wienhöfer, G.; Westerhaus, F. A.; Surkus, A.-E.; Pohl, M.-M.; Junge, H.; Junge, K.; Beller, M. Chem. Commun. 2011, 47, 10972. (h) Wang, C.; Ciganda, R.; Salmon, L.; Gregurec, D.; Irigoyen, J.; Moya, S.; Ruiz, J.; Astruc, D. Angew. Chem. Int. Ed. 2016, 55, 3091.

(11) Feng, J.; Handa, S.; Gallou, F.; Lipshutz, B. H. Angew. Chem. Int. Ed. 2016, 55, 8979.

(12) (a) Hofer, L.; Shultz, J.; Panson, R.; Anderson, R. Inorg. Chem. 1964, 3, 1783. (b) Deng, J.; Yang, J.; Sheng, S.; Chen, H.; Xiong, G. J. Catal. 1994, 150, 434. (c) He, Y.; Qiao, M.; Hu, H.; Pei, Y.; Li, H.; Deng, J.; Fan, K. Mater. Lett. 2002, 56, 952. (d) Okamoto, Y.; Nitta, Y.; Imanaka, T.; Teranishi, S. J. Chem. Soc., Faraday Trans. 1 1979, 75, 2027. (e) Schreifels, J.; Maybury, P.; Swartz, W. Jr. J. Catal. 1980, 65, 195. (f) Okamoto, Y.; Nitta, Y.; Imanaka, T.; Teranishi, S. J. Catal. 1980, 64, 397. (g) Shen, J.; Hu, Z.; Zhang, Q.; Zhang, L.; Chen, Y. J. Appl. Phys. 1992, 71, 5217. (h) Geng, J.; Jefferson, D. A.; Johnson, B. F. Chem. Commun. 2007, 969.

(13) (a) Paul, R.; Buisson, P.; Joseph, N. Ind. Eng. Chem. 1952, 44, 1006. (b) Schlesinger, H.; Brown, H. C.; Finholt, A.; Gilbreath, J. R.; Hoekstra, H. R.; Hyde, E. K. J. Am. Chem. Soc. 1953, 75, 215. (c) Ganem, B.; Osby, J. O. Chem. Rev. 1986, 86, 763.

(14) (a) Brown, H. C.; Brown, C. A. 1963, 85, 1005. (b) Brown, C. A. J. Org. Chem. 1970, 35, 1900. (c) Brown, C. A.; Ahuja, V. K. J. Org. Chem. 1973, 38, 2226.
(15) Nose, A.; Kudo, T. Chem. Pharm. Bull. 1984, 32, 2421.

(16) (a) Nose, A.; Kudo, T. Chem. Pharm. Bull. 1988, 36, 1529. (b) Nose, A.; Kudo, T. Chem. Pharm. Bull. 1989, 37, 816.

(17) (a) Khurana, J. M.; Dawra, K.; Sharma, P. RSC Adv. 2015, 5, 12048. (b) Khurana, J. M.; Arora, R. Synthesis 2009, 1127. (c) Khurana, J. M.; Magoo, D.; Dawra, K. Monatsh. Chem. 2016, 147, 1113. (d) Khurana, J. M.; Kandpal, B. M.; Kukreja, G.; Sharma, P. Can. J. Chem. 2006, 84, 1019. (e) Khurana, J. M.; Kumar, S.; Nand, B. Can. J. Chem. 2008, 86, 1052.

(18) Khurana, J. M.; Gogia, A. Org. Prep. Proced. Int. 1997, $29,1$.

(19) (a) Glavee, G. N.; Klabunde, K. J.; Sorensen, C. M.; Hadjipanayis, G. C. Langmuir 1994, 10, 4726. (b) Legrand, J.; Taleb, A.; Gota, S.; Guittet, M.-J.; Petit, C. Langmuir 2002, 18, 4131.

(20) (a) Sahiner, N.; Ozay, H.; Ozay, O.; Aktas, N. Appl. Catal., A 2010 , 385, 201. (b) Wen, H.; Yao, K.; Zhang, Y.; Zhou, Z.; Kirschning, A. Catal. Commun. 2009, 10, 1207. (c) Rahman, A.; Jonnalagadda, S. Catal. Lett. 2008, 123, 264. (d) Wu, Z.; Zhang, M.; Li, W.; Mu, S.; Tao, K. J. Mol. Catal. A: Chem. 2007, 273, 277.

(21) Liu, D.; Wu, Q.; Andersson, R. L.; Hedenqvist, M. S.; Farris, S.; Olsson, R. T. J. Mater. Chem. A 2015, 3, 15745.

(22) Wu, T.; Zeng, Z.; Siqueira, G.; De France, K.; Sivaraman, D.; Schreiner, C.; Figi, R.; Zhang, Q.; Nyström, G. Nanoscale 2020, 12, 7383.

(23) (a) Eyley, S.; Thielemans, W. Nanoscale 2014, 6, 7764. (b) Sassi, J.-F.; Tekely, P.; Chanzy, H. Cellulose 2000, 7, 119.

(24) Isogai, A.; Saito, T.; Fukuzumi, H. Nanoscale 2011, 3, 71.

(25) Sacui, I. A.; Nieuwendaal, R. C.; Burnett, D. J.; Stranick, S. J.; Jorfi, M.; Weder, C.; Foster, E. J.; Olsson, R. T.; Gilman, J. W. ACS Appl. Mater. Interfaces 2014, 6, 6127.

(26) Wei, H.; Rodriguez, K.; Renneckar, S.; Vikesland, P. J. Environ. Sci.: Nano 2014, 1, 302.

(27) Kaushik, M.; Moores, A. Green Chem. 2016, 18, 622.

(28) (a) Xu, Y.; Zhang, L.; Cui, Y. J. Appl. Polym. Sci. 2008, 110, 2996. (b) Cirtiu, C. M.; Dunlop-Briere, A. F.; Moores, A. Green Chem. 2011, 13, 288. (c) Rezayat, M.; Blundell, R. K.; Camp, J. E.; Walsh, D. A.; Thielemans, W. ACS Sustainable Chem. Eng. 2014, 2, 1241. (d) Kaushik, M.; Basu, K.; Benoit, C.; Cirtiu, C. M.; Vali, H.; Moores, A. J. Am. Chem. Soc. 2015, 137, 6124. (e) Koga, H.; Tokunaga, E.; Hidaka, M.; Umemura, Y.; Saito, T.; Isogai, A.; Kitaoka, T. Chem. Commun. 2010, 46, 8567. (f) Azetsu, A.; Koga, H.; Isogai, A.; Kitaoka, T. Catalysts 2011, 1, 83. (g) Wu, X.; Lu, C.; Zhou, Z.; Yuan, G.; Xiong, R.; Zhang, X. Environ. Sci.: Nano 2014, 1, 71. (h) Zhou, Z.; Lu, C.; Wu, X.; Zhang, X. RSC Adv. 2013, 3, 26066. (i) Chen, L.; Cao, W.; Quinlan, P. J.; Berry, R. M.; Tam, K. C. ACS Sustainable Chem. Eng. 2015, 3, 978. (j) Huang, J.-L.; Gray, D. G.; Li, C.-J. Beilstein J. Org. Chem. 2013, 9, 1388. (k) Lam, E.; Hrapovic, S.; Majid, E.; Chong, J. H.; Luong, J. H. Nanoscale 2012, 4, 997. (1) Sun, D.; Yang, J.; Li, J.; Yu, J.; Xu, X.; Yang, X. Appl. Surf. Sci. 2010, 256, 2241. (m) Wu, X.; Lu, C.; Zhang, W.; Yuan, G.; Xiong, R.; Zhang, X. J. Mater. Chem. A 2013, 1, 8645. (n) Zhou, P.; Wang, H.; Yang, J.; Tang, J.; Sun, D.; Tang, W. Ind. Eng. Chem. Res. 2012, 51, 5743. (o) Lin, X.; Wu, M.; Wu, D.; Kuga, S.; Endo, T.; Huang, Y. Green Chem. 2011, 13, 283. (p) Harrad, M. A.; Valerga, P.; Puerta, M. C.; Houssini, I.; Ali, M. A.; Firdoussi, L. E.; Karim, A. Molecules 2011, 16, 367.

(29) Prathap, K. J.; Wu, Q.; Olsson, R. T.; Dinér, P. Org. Lett. 2017, 19, 4746.

(30) (a) Galland, S.; Andersson, R. L.; Salajková, M.; Ström, V.; Olsson, R. T.; Berglund, L. A. J. Mater. Chem. C 2013, 1, 7963. (b) Olsson, R. T.; Azizi Samir, M. A. S.; Salazar-Alvarez, G.; Belova, L.; Ström, V.; Berglund, L. A.; Ikkala, O.; Nogués, J.; Gedde, U. W. Nat. Nanotechnol. 2010, 5, 584 . 
(31) (a) Hayashi, H.; Ohno, A.; Oka, S. Bull. Chem. Soc. Jpn. 1976, 49, 506. (b) Martínez-Sarti, L.; Díez-González, S. ChemCatChem 2013, 5, 1722.

(32) Arai, N.; Onodera, N.; Ohkuma, T. Tetrahedron Lett. 2016, 57, 4183.

(33) Capello, C.; Fischer, U.; Hungerbühler, K. Green Chem. 2007, 9, 927.

(34) (a) Corey, E. J.; Nicolaou, K. C.; Balanson, R. D.; Machida, Y. Synthesis 1975, 590. (b) Gartiser, T.; Selve, C.; Delpuech, J.-J. Tetrahedron Lett. 1983, 24, 1609. (c) Kotsuki, H.; Ohishi, T.; Araki, T. Tetrahedron Lett. 1997, 38, 2129. (d) Jung, Y. J.; Chang, Y. M.; Lee, J. H.; Yoon, C. M. Tetrahedron Lett. 2002, 43, 8735.

(35) Udumula, V.; Nazari, S. H.; Burt, S. R.; Alfindee, M. N.; Michaelis, D. J. ACS Catal. 2016, 6, 4423.

(36) (a) Prakash Rao, H. S.; Reddy, K. S.; Turnbull, K.; Borchers, V. Synth. Commun. 1992, 22, 1339. (b) Prakash Rao, H. S.; Siva, P. Synth. Commun. 1994, 24, 549. (c) Yoon, N. M.; Choi, J.; Shon, Y. S. Synth. Commun. 1993, 23, 3047. (d) Maddani, M. R.; Moorthy, S. K.; Prabhu, K. R. Tetrahedron 2010, 66, 329.

(37) (a) Fringuelli, F.; Pizzo, F.; Vaccaro, L. Synthesis 2000, 646. (b) Ahammed, S.; Saha, A.; Ranu, B. C. J. Org. Chem. 2011, 76, 7235.

(38) (a) Scriven, E. F.; Turnbull, K. Chem. Rev. 1988, 88, 297. (b) McDonald, F. E.; Danishefsky, S. J. J. Org. Chem. 1992, 57, 7001. (c) Cheng, J. M.; Chee, S. H.; Dölen, Y.; Verdoes, M.; Timmer, M. S.; Stocker, B. L. Carbohydr. Res. 2019, 486, 107840. (d) Nyffeler, P. T.; Liang, C.-H.; Koeller, K. M.; Wong, C.-H. J. Am. Chem. Soc. 2002, 124, 10773. (e) Sahoo, L.; Singhamahapatra, A.; Paul, K. J.; Loganathan, D. Tetrahedron Lett. 2013, 54, 5361.

(39) Rolla, F. J. Org. Chem. 1982, 47, 4327.

(40) Wuts, P. G.; Greene, T. W. Greene's Protective Groups in Organic Synthesis, 4th ed; John Wiley \& Sons: Hoboken, 2006.

(41) Ashour, R. M.; Abdel-Magied, A. F.; Wu, Q.; Olsson, R. T.; Forsberg, K. Polymers 2020, 12, 1104.
(42) (a) Jozala, A. F.; de Lencastre-Novaes, L. C.; Lopes, A. M.; de Carvalho Santos-Ebinuma, V.; Mazzola, P. G.; Pessoa, A. Jr.; Grotto, D.; Gerenutti, M.; Chaud, M. V. Appl. Microbiol. Biotechnol. 2016, 100, 2063. (b) Jeremic, S.; Djokic, L.; Ajdačić, V.; Božinović, N.; Pavlovic, V.; Manojlović, D. D.; Babu, R.; Senthamaraikannan, R.; Rojas, O.; Opsenica, I. Int. J. Biol. Macromol. 2019, 129, 351. (c) Zhang, Q.; Zhang, L.; Wu, W.; Xiao, H. Carbohydr. Polym. 2020, 229, 115454 .

(43) Saito, T.; Kimura, S.; Nishiyama, Y.; Isogai, A. Biomacromolecules 2007, 8, 2485.

(44) Iguchi, M.; Yamanaka, S.; Budhiono, A. J. Mater. Sci. 2000, 35, 261.

(45) (a) Cantillo, D.; Moghaddam, M. M.; Kappe, C. O. J. Org. Chem. 2013, 78, 4530. (b) Kantam, M. L.; Reddy, R. S.; Srinivas, K.; Chakravarti, R.; Sreedhar, B.; Figueras, F.; Reddy, C. V. J. Mol. Catal. A: Chem. 2012, 355, 96.

(46) Grimes, K. D.; Gupte, A.; Aldrich, C. C. Synthesis 2010, 1441.

(47) Gann, A. W.; Amoroso, J. W.; Einck, V. J.; Rice, W. P.; Chambers, J. J.; Schnarr, N. A. Org. Lett. 2014, 16, 2003.

(48) Salvagnini, C.; Gharbi, S.; Boxus, T.; Marchand-Brynaert, J. Eur. J. Med. Chem. 2007, 42, 37.

(49) Maury, J.; Feray, L.; Bertrand, M. P.; Kapat, A.; Renaud, P. Tetrahedron 2012, 68, 9606.

(50) Dryzhakov, M.; Hellal, M.; Wolf, E. N.; Falk, F. C.; Moran, J. J. Am. Chem. Soc. 2015, 137, 9555.

(51) Morrison, Z. A.; Nitz, M. Org. Lett. 2020, 22, 1453.

(52) Menuel, S. P.; Doumert, B.; Saitzek, S. B.; Ponchel, A.; Delevoye, L.; Monflier, E.; Hapiot, F. D. R. J. Org. Chem. 2015, 80, 6259.

(53) Burland, P. A.; Osborn, H. M.; Turkson, A. Bioorg. Med. Chem. 2011, 19, 5679.

(54) Ryu, B.-Y.; Emrick, T. Angew. Chem. Int. Ed. 2010, 49, 9644.

(55) Xie, S.; Lopez, S. A.; Ramström, O.; Yan, M.; Houk, K. J. Am. Chem. Soc. 2015, 137, 2958. 